$10-1-2013$

\title{
Tax Credit Scholarship Programs and the Changing Ecology of Public Education
}

Hillel Y. Levin

University of Georgia School of Law, hlevin@uga.edu

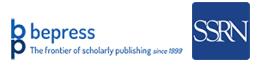

\section{Repository Citation}

Hillel Y. Levin, Tax Credit Scholarship Programs and the Changing Ecology of Public Education , 45 Ariz. St. L.J. 1033 (2013),

Available at: https://digitalcommons.law.uga.edu/fac_artchop/953

This Article is brought to you for free and open access by the Faculty Scholarship at Digital Commons @ University of Georgia School of Law. It has been accepted for inclusion in Scholarly Works by an authorized administrator of Digital Commons @ University of Georgia School of Law. Please share how you have benefited from this access For more information, please contact tstriepe@uga.edu. 


\title{
TAx CRedit SChOlarship Programs AND the Changing Ecology of Public EDUCATION
}

\author{
Hillel Y. Levin*
}

\begin{abstract}
The traditional model of public education continues to be challenged by advocates of school choice. Typically associated with charter schools, magnet schools, and tuition voucher programs, these advocates have recently introduced a new school choice plan, namely tax credit scholarship programs. More than a dozen states have adopted such programs, and hundreds of millions of dollars are now diverted each year from public programs to private schools. These programs are poorly understood and under-studied by legal scholars. This Article assesses the place of these programs within the ecology of public education, considers the fundamentally different approaches states have taken to these programs, identifies some critical questions and problems with them, and proposes a set of best practices for states to follow in designing and implementing them.
\end{abstract}

* Hillel Y. Levin is Associate Professor of Law at the University of Georgia School of Law. He thanks John Dayton, Jennifer Rippner, and Jeremy Berry for their helpful suggestions and critiques. He is also grateful to Robert Jacques, Crystal Johnson, Kenney Bentley, and TJ Striepe for their excellent research assistance. Disclaimer: The author, a resident of Georgia, contributes to a student scholarship organization, and his children attend a private school that benefits from the organization. 


\section{TABLE OF CONTENTS}



II. The Changing Ecology of Public Education ................................1039

A. The School Choice Movement and Its Successes (and Failures) 1039

B. The History and Development of Tax Credit Scholarship

Programs 1047

III. The Particulars of AND Problems With TAX CREDIT SCHOLARSHIP PROGRAMS .1052

A. Different States, Different Programs..............................................1052

1. Programs with Robust Eligibility Requirements and Accountability Measures: Alabama, Florida, Louisiana, Indiana, Iowa, Virginia 1052

2. Programs with Moderate Eligibility Requirements and Accountability Measures: Pennsylvania, Rhode Island, Oklahoma, New Hampshire 1056

3. Programs with Few Eligibility Requirements and Accountability Measures: Arizona, Georgia

B. The Justification/Effect Mismatch and the Potential for Abuse....1061

C. Do Tax Credit Scholarship Programs Improve Educational

Outcomes? 1063

IV. BEST PRACTICES FOR TAX CREDIT SCHOLARSHIP PROGRAMS...............1066



B. Educational Accountability ..........................................................1070

C. Total Expenditures, Tax Credit Value, and Contribution Limits 1072

Conclusion: The Best Practice That Matters Most .1073 


\section{INTRODUCTION}

Not long ago, public funding of primary and secondary education seemed like a straightforward proposition. Public funds were collected from taxes and spent on local public schools. Families did not have a choice as to where their children attended public school. ${ }^{1}$ Over the past several years, however, the ecology of public education has experienced dramatic change. ${ }^{2}$ Under the banner of school choice, public funds continue to support traditional public schools, but they are now also spent on charter schools ${ }^{3}$ and magnet schools, ${ }^{4}$ and they even flow to private schools through voucher programs $^{5}$ and tax credit scholarship programs. ${ }^{6}$

These changes to our public education system raise substantial legal, political, social, and educational questions, many of which have received

1. Of course, parents could opt to homeschool their children and, in many locations, those who could afford private school tuitions (or received private scholarship funding) had the additional option of sending their children to private schools. Furthermore, parents with the means and opportunity to do so could choose to live in districts with especially good public schools.

2. See, e.g., Ronald G. Corwin \& E. Joseph Schneider, The School Choice HoAx 7 (2005) (hypothesizing that the school choice movement was a response to rapid social changes in urbanization, increased immigration, and growing diversity); Bruce R. Van Baren, Comment, Tuition Tax Credits and Winn: A Constitutional Blueprint for School Choice, 24 REGENT U. L. REV. 515, 526 (2012) ("The phenomenon of school choice has swept across the country. Charter schools, virtual schooling, homeschooling, vouchers, and many other options are now available to parents seeking an alternative to the educational status quo.").

3. The District of Columbia and all but eleven states have some form of charter school system. Numbers and Types of Public Elementary and Secondary Schools From the Common Core of Data: School Year 2010-2011, Table 2 (2012), NAT'L CENTER FOR EdUC. STAT., available at http://nces.ed.gov/pubs2012/pesschools10/tables/table_02.asp.

4. The District of Columbia and all but sixteen states have some form of magnet program. $I d$.

5. Twelve states and the District of Columbia have a voucher system. The states are: Arizona, Colorado, Florida, Georgia, Indiana, Louisiana, Maine, Ohio, Oklahoma, Utah, Vermont, and Wisconsin. Becky Vevea, What is a School Voucher?, GREAT SCHOOLS, http://www.greatschools.org/school-choice/7200-school-vouchers.gs (last visited Sept. 28, 2013).

6. Twelve states currently have some form of scholarship tax-credit program. Those states are: Alabama, Arizona, Florida, Georgia, Indiana, Iowa, Louisiana, New Hampshire, Oklahoma, Pennsylvania, Rhode Island, and Virginia. Bill Chappell, Alabama's Governor Signs Education Bill Allowing School Choice, NAT'L PUB. RADIO (Mar. 14, 2013, 12:23 PM), http://www.npr.org/blogs/thetwo-way/2013/03/14/174297267/alabamas-governor-signseducation-bill-allowing-school-choice; Emily Workman, Vouchers, Scholarship Tax Credits, and Individual Tax Credits and Deductions, EDUC. COMM'N OF THE STATES 9-13 (Oct. 2012), available at http://www.ecs.org/clearinghouse/01/04/76/10476.pdf. 
attention from researchers in relevant fields. ${ }^{7}$ However, the rapidly expanding trend of states extending tax credits to taxpayers who donate to scholarship organizations $^{8}$ that support private education has been understudied and is the least understood among the various school choice schemes. Legal scholars have written a great deal about the constitutionality of such tax credit scholarship programs ${ }^{9}$ - a question that was essentially

7. See generally, e.g., EDUCATION GOVERNANCE FOR THE TWENTY-FIRST CENTURY: Overcoming the Structural BARRIERs TO SchoOl REFORM (Paul Manna \& Patrick McGuinn eds., 2013) (evaluating various approaches to school choice governance issues);

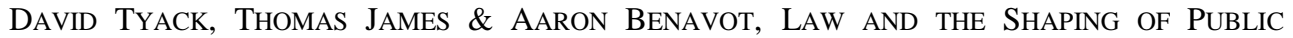
EducATiOn: 1785-1954 (1987); Herbert J. WALBERG, School CHOICE: ThE Findings (2007) (evaluating the effects of charter schools and education vouchers on overall educational quality in the United States); Kenneth R. Howe, Evidence, the Conservative Paradigm, and School Choice, in School CHOICE Policies AND Outcomes 61, 61-78 (Walter Feinberg \& Christopher Lubienski eds., 2008) (discussing the political influences that color evidence gathering to evaluate school choice programs); Christopher Lubienski, The Politics of Parental Choice: Theory and Evidence on Quality Information, in SCHOOL CHOICE POLICIES AND OuTCOMES 99, 100-09 (Walter Feinberg \& Christopher Lubienski eds., 2008) (describing and evaluating the most common political arguments for and against school choice); Neal P. McCluskey, One Size Does Fot All, N.Y. TIMES (Dec. 7, 2012), http://www.nytimes.com/roomfordebate/2012/01/24/should-parents-control-what-kids-learn-atschool/one-size-does-not-fit-all (last updated Dec. 7, 2012).

8. Scholarship organizations go by different names in different states. E.g., ARIZ. REV. STAT. § 43-1602 (2012) (permitting nonprofit organizations to apply for certification as a "school tuition organization"); FLA. STAT. § 1002.395(2)(f) (2013) (defining "[e]ligible nonprofit scholarship-funding organization"); GA. CODE ANN. § 20-2A-1(3) (2013) (defining "[s]tudent scholarship organization"); IND. CODE § 20-51-3-3 (2013) (stating requirements of "scholarship granting organization[s]"); 72 PA. CONS. STAT. § 8702-F (2013) (defining "[e]ducational improvement organization" and "[p]re-kindergarten program"). However, they all serve the same function and operate similarly. Therefore, for the sake of consistency and simplicity I use the term scholarship organization throughout this Article to refer to all such organizations.

9. See, e.g., R. CRAig Wood, Educational Finance Law: Constitutional Challenges to State Aid Plans-An Analysis of Strategies 55-58 (3d ed. 2007) (evaluating methods to attack the constitutionality of school choice funding programs); Allison Fetter-Harrott \& Martha McCarthy, A Perplexing Step Backward for the Establishment Clause and a Winn for School Privatization, 270 ED. LAW REP. 1, 11-15 (2011) (opining that the majority opinion in Arizona Christian School Tuition Organization v. Winn, which upheld Arizona's tuition tax credit scholarship program granting tax credits for contributions to scholarship trust organizations that could fund parochial education, conflicted with the Supreme Court's Establishment Clause precedent and should have been found unconstitutional); William G. Frey \& Virginia Lynn Hogben, Vouchers, Tuition Tax Credits, and Scholarship-Donation Tax Credits: A Constitutional and Practical Analysis, 31 STETSON L. REV. 165, 185-89 (2002) (concluding the Arizona and Pennsylvania tax credit scholarship programs likely pass constitutional muster); Phillip E. Johnson, Concepts and Compromise in First Amendment Religious Doctrine, 72 CALIF. L. REV. 817, 822-23 (1984) (noting the question of granting religious private schools the same benefits as secular private schools through "tuition tax credits, grants, or other forms of aid" highlights the tension between the "no assistance" 
settled by the Supreme Court recently, at least with respect to the United States Constitution ${ }^{10}$ - but vanishingly little has been written about why a dozen states, including such diverse states as Arizona, ${ }^{11}$ Pennsylvania, ${ }^{12}$ Florida, ${ }^{13}$ Georgia, ${ }^{14}$ Iowa, ${ }^{15}$ and others, have experimented with these programs, how they work in practice, what they accomplish, and what they portend for the future of public education.

This Article aims to fill this lacuna by casting a careful eye on the tax credit scholarship programs around the country. Although such programs are typically lumped together — when they are discussed at all—by scholars as an undifferentiated mass, ${ }^{16}$ the truth is that programs differ fundamentally from one another in form and function. ${ }^{17}$ By carefully reviewing states' varying approaches to tax credits, we can identify specific trends and consider potential social and educational problems and questions raised by these different approaches. In some cases, there is a disturbing mismatch

principle of the Establishment Clause and the "no discrimination" principle of the Free Exercise Clause); Laura Underkuffler-Freund, The Separation of the Religious and the Secular: A Foundational Challenge to First Amendment Theory, 36 WM. \& MARY L. REV. 837, 930 (1995) ("Whatever the particular intentions of the framers of [the Constitution], it is clear that an 'establishment,' in the general understanding of the time, encompassed any tax monies given directly to a religious institution, whether designated by the state or by the taxpayer's choice.").

10. In 2011, the Supreme Court held that taxpayers do not have Article III standing to bring an Establishment Clause challenge to a state tax credit for contributions to school tuition organizations that fund religiously affiliated private schools. Ariz. Christian Sch. Tuition Org. v. Winn, 131 S. Ct. 1436, 1440 (2011).

11. ARIZ. REV. STAT. § 43-1089 (2012) (creating individual tax credits for contributions to certified scholarship tuition organizations).

12. 72 PA. CONS. STAT. $\S \S 8701-F, 8701-G .1$ (2012) (extending tax credit to business firms, but not individual taxpayers).

13. Fla. STAT. $\$ 1002.395$ (2012) (creating and defining the Florida Tax Credit Scholarship Program).

14. GA. CODE ANN. § 48-7-29.16 (2012) (defining the individual and corporate tax credit for contributions to student scholarship organizations); id. $\S 20-2 \mathrm{~A}-1$ to 7 (defining guidelines for student scholarship organizations).

15. IOWA CODE $\S 422.12(2)(b)$ (2013) (granting a credit of $25 \%$ of the first thousand dollars a taxpayer pays for each dependent attending an accredited school).

16. See, e.g., Stefani Carter, School Tax Credits, 39 HARV. J. ON LEGIS. 521, 524-26 (2002) (advocating generally a federal tax credit scholarship program without evaluating individual tax credit structures); Nicole Stelle Garnett, Affordable Private Education and the Middle Class City, 77 U. CHI. L. REV. 201, 215-16 (2010) (advocating tax credit scholarship programs to make private education more affordable for middle class families in urban areas without identifying a particularly beneficial structure to the program).

17. The tax credit scholarship programs vary in terms of who receives the tax credit - an individual or a business organization, student eligibility standards, scholarship granting organization qualification requirements, scholarship cap, and tax credit limits. Workman, supra note 6 , at $9-14$. 
between the stated aims of many such programs (assisting the relatively underprivileged $^{18}$ ) and their apparent effects (subsidizing the private education of the middle and upper class ${ }^{19}$ ). There is also much opportunity for systemic abuse within some programs, and their effect on academic achievement is questionable at best. By identifying such concerns, we can develop a series of best practices for states to follow in designing tax credit scholarship programs.

The Article proceeds as follows. Part II begins by discussing the social and legal context of our changing public education ecology. It then introduces tax credit scholarship programs, placing them within this larger landscape, and considers why they have received little attention from scholars as compared to other aspects of the school choice movement. Part III then undertakes a careful state-by-state analysis of the extant tax credit scholarship programs and highlights several areas of substantial variation. Part III then identifies potential problems implicated by particular features of some states' approaches. Part IV proposes some guidelines and best practices for states considering (or reconsidering) such programs in the hopes of bringing them in line with their stated purposes. Finally, the Article concludes by considering some broader questions about the school choice movement in light of the findings concerning tax credit scholarship programs.

18. See, e.g., ARIZ. SCH. CHOICE TRUST, http://www.asct.org/ (last visited Sept. 29, 2013) (advertising an Arizona individual and corporate tax credit scholarship program as a means of helping economically disadvantaged students); School Choice, FOCUS ON THE FAMILY, http://www.focusonthefamily.com/socialissues/social-issues/school-choice.aspx (last visited Sept. 29, 2013) (stating school choice programs help underprivileged and middle class families send their children to private school because the tax credit prevents the family from "double pay[ing]" for education - the private education they choose and the public education funded through their tax dollars).

19. See, e.g., Carter, supra note 16, at 530 ("[T] ax credits would only increase the ability of wealthier parents to pay higher tuition at better schools, leaving less-privileged children behind at the less effective schools"); Garnett, supra note 16, at 215 (arguing for tax credits as a tool to make urban areas more attractive to middle class families). 


\section{The Changing Ecology of Public EducAtion}

\section{A. The School Choice Movement and Its Successes (and Failures)}

The origins of the modern school choice movement, ${ }^{20}$ comprised of parents and other reformers seeking state funding for alternatives to

20. An earlier iteration of the school choice movement developed as a result of the introduction of state public education systems and, eventually, compulsory attendance laws. This earlier iteration established the conditions for the modern movement and reflected some similar themes concerning the relationship and tension between a majoritarian and pluralistic society on the one hand, and the interests of minority and religious groups on the other.

Massachusetts was the first state to enact a mandatory school statute in 1789, which required communities to establish elementary schools. STEVEN K. GREEN, THE BIBLE, THE School, AND THE CONSTITUTION 18 (2012). By the mid-nineteenth century, public education became "the vehicle in which children of all groups would be educated for democratic citizenship." Rob Reich, Common Schooling and Educational Choice as a Response to Pluralism, in SCHOOL Choice Policies AND OutComes 21, 24 (Walter Feinberg \& Christopher Lubienski eds., 2008). Many of these schools adopted explicitly religious curricula reflecting the dominant Protestant religious ideology of the times. GREEN, supra, at 46; Mark Edward DeForrest, An Overview and Evaluation of State Blaine Amendments: Origins, Scope, and First Amendment Concerns, 26 HARV. J.L. \& PUB. POL'Y 551, 559 (2003) ("While professing to be free of sectarianism, the common schools were actually propagators of a generic Protestantism . . . Readings from the Protestant King James Bible were a common part of the curriculum ....").

It was not until the wave of Catholic and Jewish immigration beginning in the 1830's that this practice became an issue. GREEN, supra, at 54-68 (describing the change in the public debate over public school funding and curriculum fueled by Catholic immigration in New York). As they grew in numbers, Catholics in particular fought against the Protestantism of public schools. DeForrest, supra, at 560-61. They challenged the reading of the King James Bible in schools and sought government funding for their own sectarian schools. Id. at 560 . Many states responded by adopting so-called Blaine Amendments to their constitutions, which banned the expenditure of public funds on sectarian institutions. Id. at 564-76. Additionally, some states adopted compulsory education laws that required children to attend public schools and prohibited or severely proscribed private and home schooling. Martha Minow, Confronting the Seduction of School Choice: Law, Education, and American Pluralism, 120 YALE L.J. 814, 819 (2011).

The struggle over school choice between the white Protestant nativists and minority religious groups culminated with the case Pierce v. Society of the Sisters, 268 U.S. 510, 534-35 (1925), in which the Supreme Court declared that parents and guardians have a fundamental right to "direct the upbringing and education of children under their control.". In Pierce, "nativist anxiety about waves of immigrants and Bolshevism . . . . took an extreme form in Oregon where the Ku Klux Klan, Federated Patriotic Societies, Scottish Rite Masons, and other groups, pushed not only for compulsory schooling but also required attendance at public schools in particular. The reformers sounded white supremacist, anti-Catholic, and anti-Semitic tones while pushing assimilation of immigrants into 'American' culture-meaning white Protestantism." Id.

The Court in Pierce stated that the "fundamental theory of liberty upon which all governments in this Union repose excludes any general power of the state to standardize its children by forcing them to accept instruction from public teachers only" because " $\mathrm{t}] \mathrm{he}$ child is 
universal public education, can be traced to three factors. First, the secularization of the public schools attributable to the Supreme Court's Establishment Clause jurisprudence caused some religious parents to seek educational alternatives in which they could inculcate their religious values to their children. ${ }^{21}$ Second, the Supreme Court's 1954 decision in Brown v. Board of Education ${ }^{22}$ - and subsequent integrationist judicial opinions ${ }^{23}$ led some parents to enroll their children in segregated private schools. ${ }^{24}$ Finally, in 1955, Milton Friedman published an influential essay advocating a free market education system and proposing a school voucher program. ${ }^{25}$

not the mere creature of the state; those who nurture him and direct his destiny have the right, coupled with the high duty, to recognize and prepare him for additional obligations." 268 U.S. at 535 .

In one sense, Pierce affirmed the principle of school choice in that it stands for the proposition that parents have the right to opt out of the public schools in favor of other alternatives. However, it effectively established a two-tier system that persisted, with little change, until it came under pressure relatively recently: one option-public schools-were paid for by the state from tax revenues; the other options - private and home schools - would not be funded by the government. Minow, supra, at 819-20.

As time marched on, the Supreme Court prohibited the teaching of religion in public schools. John C. Jeffries, Jr. \& James E. Ryan, A Political History of the Establishment Clause, $100 \mathrm{MiCH}$. L. REV. 279, 288-89 (2001). This helped to set the stage, in part, for the modern school choice movement, which includes a strong religious cohort seeking funding for private religious schools. Minow, supra, at 819-20.

21. See James Forman, Jr., The Rise and Fall of School Vouchers: A Story of Religion, Race, and Politics, 54 UCLA L. REV. 547, 560-61 (2007) (chronicling the development of the religious critique of public school).

22. 347 U.S. 483 (1954) (holding that the "separate but equal" doctrine has no place in public education); see also Brown v. Bd. of Educ., 349 U.S. 294, 300-01 (1955) (providing guidance for how courts should evaluate desegregation plans).

23. E.g., Raney v. Bd. of Educ., 391 U.S. 443, 449 (1968) (holding that precedent contemplates for courts to retain jurisdiction over cases involving the disestablishment of stateestablished segregated schools); Rogers v. Paul, 382 U.S. 198, 200 (1965) (vacating lower court's decision declining to find standing on the basis that it exists only for students presently in desegregated schools); Bradley v. Sch. Bd., 382 U.S. 103, 103, 105 (1965) (holding that it was improper not to consider "the impact on [desegregation] plans of faculty allocation on an alleged racial basis"); Griffin v. Cnty. Sch. Bd., 377 U.S. 218, 232 (1964) (“[C]losing the Prince Edward schools and meanwhile contributing to the support of the private segregated white schools that took their place denied petitioners the equal protection of the laws."); Goss v. Bd. of Educ., 373 U.S. 683, 684-85 (1963) (striking a plan for permitting transfers solely on the basis of the student's race and school's racial composition so as to perpetuate segregation); McNeese v. Bd. of Educ., 373 U.S. 668, 670, 674-75 (1963) (permitting suit under federal law despite an argument that state processes were not sufficiently exhausted); Cooper v. Aaron, 358 U.S. 1, 4 (1958) (refusing to uphold a suspension of Little Rock's plan to desegregate public schools).

24. Minow, supra note 20 , at 816.

25. Milton Friedman, The Role of Government in Education, in ECONOMICS AND THE PUBlic INTEREST 123 (Robert A. Solo ed., 1955). 
These three forces-what we might identify as religious insulationism, racism, and market-based reformism - created the context for the modern school choice movement. This is not to say that all of these forces or the interest groups they correlate with are coextensive. Obviously, it is possible to be religious or to advocate market-based reforms without being racist. But these background forces together created the dynamics that initially shaped the modern movement. For example, although Friedman insisted that his voucher solution, which "emphasized that vouchers would promote a free society, produce competition, and improve schooling,",26 was unrelated to the Court's move to desegregate schools,${ }^{27}$ Southern states were the first to use his free market theory post-Brown. ${ }^{28}$ Examples of school choice used to thwart desegregation included vouchers to fund and support private schools that opened to educate white children, plans that allowed students to opt out of desegregated schools in favor of private schools, and an ostensibly choice-based system that required students to opt in to newlydesegregated schools from their traditionally segregated one. ${ }^{29}$ These practices persisted until the Supreme Court struck "freedom of choice" plans as insufficient to fulfill school districts' obligation to desegregate in $1968 .^{30}$

These forces, broadly aligned with the conservative political movement, gained unlikely allies in the 1970s and 1980s when some progressives and liberals began to advocate for school choice as a means of furthering the principles of racial equality in education. ${ }^{31}$ School choice initiatives developed by these reformers took the form of (1) magnet schools (public schools that emphasize a special curricular focus designed to attract a high performing, diverse student body or to provide better overall educational opportunities), ${ }^{32}$ (2) charter schools (publicly-funded schools that operate outside of many laws and practices applicable to the normal public

26. Minow, supra note 20 , at 822 .

27. Friedman, supra note 25, at $131 \mathrm{n} .2$.

28. See Erica Frankenberg \& Genevieve Siegel-Hawley, Choosing Diversity: School Choice and Racial Integration in the Age of Obama, 6 STAN. J. C.R. \& C.L. 219, 223 (2010) ("Public vouchers to private segregation academies, freedom of choice plans and open enrollment all serve as early examples of school choice used to thwart desegregation."); Minow, supra note 20, at 822 ("White Southerners did, in fact, use school choice practices as a form of resistance to court-ordered desegregation.").

29. Minow, supra note 20, at 822-23; Frankenberg \& Siegel-Hawley, supra note 28, at $223-24$.

30. Green v. Cnty. Sch. Bd., 391 U.S. 430, 440-41 (1968).

31. Minow, supra note 20, at 824.

32. Id. at $824-25$. 
education system), ${ }^{33}$ and (3) private school vouchers (to expand educational options for low-income families stuck in failing public schools). ${ }^{34}$

Currently, magnet programs represent the largest school choice program in the country. In the 2010-2011 school year, there were over 2,700 magnet schools educating over two million students nationwide. ${ }^{35}$ Initially, some federal district courts used magnet schools as a tool to facilitate voluntary majority-to-minority transfers to achieve desegregation. ${ }^{36}$ However, the Supreme Court halted this practice in 1995 when it rejected a court-ordered desegregation plan for Kansas City, Missouri that included an interdistrict magnet school designed to attract students from outside the district because the scope of the plan exceeded the limits of the mandate to remedy segregation within the specific district. ${ }^{37}$ As a result, though some districts voluntarily form interdistrict magnet programs, the majority of programs today are intradistrict schools with limited geographic scope. ${ }^{38}$ Critics of magnet schools consider the programs to be a drain on non-magnet school funding and object to the use of race as a factor for enrollment in highly competitive programs. ${ }^{39}$ But to offset these costs, some federal funding is available for magnet schools. ${ }^{40}$

Although magnet programs are older and more prevalent, charter schools have recently emerged as the "kudzu" of school choice. ${ }^{41}$ Charter schools

33. Ron Zimmer, Brian Gill, Kevin Booker, Stéphane Lavertu \& John F. Witte, Charter Schools: Do They Cream Skim, Increasing Student Segregation?, in SCHOOL CHOICE AND SCHOOL IMPROVEMENT 215 (Mark Berends, Marisa Cannata \& Ellen B. Goldring eds., 2011).

34. See WALBERG, supra note 7, at 35-36 (describing voucher programs and the goal to alleviate poverty).

35. NAT'L CENTER FOR EDUC. STAT., supra note 3, at tbls. 2-3.

36. See, e.g., Ross v. Houston Indep. Sch. Dist., 699 F.2d 218, 222 (5th Cir. 1983); Arthur v. Nyquist, 712 F.2d 809, 811 (2d Cir. 1983) (ordering a magnet program in Buffalo school district); Armstrong v. Bd. of Sch. Dir. of Milwaukee, 471 F. Supp. 800, 815, 819 (E.D. Wis. 1979).

37. Missouri v. Jenkins, 515 U.S. 70, 76-77, 100 (1995).

38. James E. Ryan \& Michael Heise, The Political Economy of School Choice, 111 YALE L.J. 2043, 2064-65, 2070 (2002).

39. Minow, supra note 20, at 826. After Parents Involved in Community Schools v. Seattle School District No. 1, 551 U.S. 701 (2006), this criticism may be fatal to magnet school selection criteria. The Court held that "[h]owever closely related race-based assignments may be to achieving racial balance, that itself cannot be the goal, whether labeled 'racial diversity' or anything else." Id. at 733.

40. Congress first provided grants to districts developing magnet schools in a 1972 amendment to the Emergency School Aid Act. Though this program was defunded by Reagan budget cuts, Congress passed the Magnet Schools Assistance Program in the mid-1980s to provide incentives to schools developing magnet schools. See Frankenberg \& Siegel-Hawley, supra note 28, at 225-26.

41. Ryan \& Heise, supra note 38, at 2074. 
are "a cross between a public and a private school." 42 James E. Ryan and Michael Heise describe charter schools thusly:

Authorized by state statutes, [charter] schools are publicly funded, tuition-free, nonsectarian schools that operate pursuant to a contract between the school and the chartering agency, which is either the local school board, a state agency, or a state-designated agency. The schools themselves can be newly created schools, converted public schools, or converted private schools. They can be opened and operated by any number of groups, including teachers, parents, and private corporations, although some states require that the charter school creators be a nonprofit group. The schools are freed from complying with various regulationsrelating to such issues as teacher hiring, curriculum, calendar, and length of school day-in exchange for accountability for performance. The core idea behind charters is to grant greater flexibility to schools in exchange for greater accountability, which includes the threat of closure if a school fails to perform adequately. ${ }^{43}$

"Federal backing for school choice exploded with the advent of charter schools." 44 Perhaps because, unlike magnet schools, pure educational quality and not racial diversity is the primary driving factor for charter schools, they receive more bipartisan support. ${ }^{45}$ Starting with the first Bush administration and expanding with every administration since, federal funding of charter schools went from \$6 million in 1995 to \$217 million in $2005,{ }^{46}$ and to $\$ 372$ million in $2012 .^{47}$ One commentator calls charter schools the "it" policy for education reform that are now "firmly embedded in twenty-first-century education policy." 48 Despite being outnumbered, charter schools received twice as much federal funding as magnet schools. ${ }^{49}$ President Obama's administration included charter incentives in his Race to the Top education program, and made it a priority to double federal charter school funding in his first administration. ${ }^{50}$ The first charter school was

42. Id. at 2073 .

43. Id. at 2073-74.

44. Frankenberg \& Siegel-Hawley, supra note 28, at 228.

45. Id. at $229,242-45$.

46. Id. at 228 .

47. U.S. DeP'T of Educ., The Federal Budget Fiscal Year 2012, available at http://www.whitehouse.gov/omb/factsheet_department_education/ (last visited Sept. 29, 2013).

48. Frankenberg \& Siegel-Hawley, supra note 28, at 228.

49. Id. at 243 .

50. Id. at $229,243$. 
opened in 1992 in Minnesota. ${ }^{51}$ In the 2010-2011 school year, there were 5,274 charter schools in 39 states and the District of Columbia educating almost 1.8 million students. ${ }^{52}$

Because they are created by statute, charter schools vary from state to state. However, they share similarities that limit their ability to provide the choice some parents seek. First, charter schools are usually limited to serving students in their immediate district or attendance zone. ${ }^{53}$ Second, most are funded by a combination of state and local aid, and school boards often have the authority to block competing charter schools. ${ }^{54}$ Third, most charter schools are located in urban districts; thus, they do not often reach students in suburban and rural areas. ${ }^{55}$ Finally, because charter schools are state affiliated, they do not provide an outlet for parents wishing to expose their children to religious education. ${ }^{56}$

Whereas charter schools serve the purposes of only some school reformers - those who wish to provide public and non-sectarian alternatives to traditional public schools in order to radically change the public educational system from within the system-private school vouchers offer an alternative school choice approach that appeals to others, namely those who want a way to opt out of the public school system altogether with financial support from the government. Vouchers are intended to expand choice on a student-by-student basis while taking students out of the public school system entirely, rather than create new kinds of public schools.

Programs awarding vouchers to individual students based on Friedman's concept of an educational marketplace were initially met with bipartisan success in the 1980s. ${ }^{57}$ Liberal reformers initially supported vouchers as a solution to overcrowded urban schools and a means of accessing private education when public education was inadequate; conservatives supported vouchers as a means of providing parochial educational options to parents who wanted to send their children to religious schools. ${ }^{58}$ During the Reagan

51. Ryan \& Heise, supra note 38, at 2074.

52. NAT'L CENTER FOR EDUC. STAT., supra note 3, at tbls. 2-3.

53. Ryan \& Heise, supra note 38 , at 2075.

54. Id. at 2075-76.

55. Id. at 2076 .

56. Although charter schools are freed from many restraints imposed on traditional public schools, they are still subject to constitutional restrictions concerning the separation of Church and State. Consequently, they are prohibited from adopting any kind of religious character.

57. Frankenberg \& Siegel-Hawley, supra note 28, at 227-28. But see Ryan \& Heise, supra note 38, at 2078-82 (describing school voucher opposition from both parties).

58. Minow, supra note 20, at 829 ("[A]dvocates for poor children of color joined forces with free-market supporters and endorsers of public aid for parochial schools to seek publicly funded school choice programs that would include private religious schools."). 
era, vouchers were employed in a piecemeal fashion to address overcrowded urban schools and declining inner-city schools. ${ }^{59}$ For conservative Christians unhappy with the secularization of public schools and Supreme Court decisions removing all signs of religion from public schools, vouchers were also seen as a means of funding private religious instruction to preserve the parents' religious teachings. ${ }^{60}$

The Supreme Court upheld a voucher program against an Establishment Clause challenge in the seminal 2002 case Zelman v. Simmons-Harris, ${ }^{61}$ seemingly opening the door for the proliferation of voucher programs funding religious education. Zelman was celebrated by the choice movement as a "triumph of pluralism." ${ }^{62}$ However, state voucher programs have failed to take off. ${ }^{63}$ When Zelman was decided, three states had voucher programs for economically disadvantaged students ${ }^{64}$ and two states had voucher programs for students residing in districts with no public school. ${ }^{65}$ In more than a decade since, only three jurisdictions have adopted voucher programs for low-income students, ${ }^{66}$ while seven jurisdictions have programs for students with disabilities. ${ }^{67}$ Since Zelman settled the federal constitutional issue, voucher proposals have failed in over thirty-four states. ${ }^{68}$

Some commentators attribute this stagnation in the development of new voucher programs to concerns that vouchers would not survive challenges brought under state constitutions. ${ }^{69}$ Others attribute it to the main proponents of vouchers, conservative Christians, ${ }^{70}$ turning away from the

59. Frankenberg \& Siegel-Hawley, supra note 28, at 228.

60. Forman, supra note 21, at 563-64 ("[P]roponents of the values claim [that parents, not the State, have the authority to direct their child's education] say that parents should be able to send their children to a school that is not hostile to their fundamental beliefs. They say that parents should not have to send their children to schools that teach them that their parents are wrong.").

61. 536 U.S. 639 (2002).

62. Joseph P. Viteritti, Reading Zelman: The Triumph of Pluralism, and its Effects on Liberty, Equality, and Choice, 76 S. CAL. L. REV. 1105, 1106-07 (2003).

63. Frankenberg \& Siegel-Hawley, supra note 28, at 228; Forman, supra note 21, at 549.

64. Forman, supra note 21, at 549; accord Patrick J. Wolf, School Voucher Programs: What the Research Says about Parental School Choice, 2008 B.Y.U.L. REV. 415, 419 tbl.1 (2008).

65. Wolf, supra note 64, at 419 tbl.1.

66. Forman, supra note 21, at 547.

67. Wolf, supra note 64, at 418 tbl.1.

68. Forman, supra note 21, at 550.

69. Frankenberg \& Siegel-Hawley, supra note 28, at 228.

70. Forman, supra note 21 , at 550 (noting that "religious conservatives-especially Christian conservatives - once championed school vouchers and other forms of private school 
option due to fear of government oversight of private religious schools receiving voucher funding when the No Child Left Behind Act was passed the same year the Supreme Court decided Zelman, ${ }^{71}$ and the rise of the accountability movement in education and government oversight of educational programs receiving vouchers generally. ${ }^{72}$ Furthermore, the differences between voucher programs functionally serving the ends sought by Christian proponents motivated by religious values and proponents motivated by racial equality in education are not easily reconciled. The racial equality camp seeks vouchers that benefit low-income students in failing public school districts, whereas low-income vouchers often would not serve the ends of conservative religious camps. ${ }^{73}$ Thus, voucher programs have lost some of their appeal as a bipartisan and unifying issue.

Still, vouchers have not altogether disappeared from the school choice landscape. For example, in January 2004, President George W. Bush signed into law the District of Columbia School Choice Initiative Act of $2003,{ }^{74}$ establishing the first federally funded private school voucher system in the United States for school children in the nation's capital. ${ }^{75}$ A lottery system was implemented to determine which students would receive vouchers due to the number of applicants. ${ }^{76}$ However, in 2009, a federal appropriations law closed the voucher program to new applicants. ${ }^{77}$ As of the 2011 budget proposal, the program was in a winding down phase. ${ }^{78}$ In sum, the voucher movement as a whole, which initially held great promise for proponents of school choice, seems to have stalled politically.

choice as their leading education priority ... [b]ecause they sought schools that would reinforce their religious beliefs and values ...").

71. Forman, supra note 21, at 551. Forman opines that "[a]lthough No Child Left Behind does not govern private schools receiving vouchers, there is growing pressure for increased government oversight of those schools. This threat of governmental regulation is anathema to conservative Christian educators, driving them further away from a school voucher movement about which they were already increasingly ambivalent." Id.

72. Id. at 552-53; see also id. at 565 (arguing that leaving schools largely unregulated was "essential to capturing the support of the evangelical community").

73. Id. at 552 .

74. Title III of Division C of the Consolidated Appropriations Act, 2004, Pub. L. No. 108199, 118 Stat. 3.

75. Patrick J. Wolf, Brian Kisida, Babette Gutmann, Michael Puma, Louis Rizzo \& Nada Eissa, School Vouchers in the Nation's Capital, in SCHOOL CHOICE AND SCHOOL IMPROVEMENT 17 (Mark Berends, Marisa Cannata \& Ellen B. Goldring eds., 2011).

76. Id.

77. Id. at 18 .

78. Id. (citing OfFICE OF MGMt. \& Budget, Exec. OfFice of THE President, Budget of THE United States Government, Fiscal Year 2011, Appendix: Other Independent Agencies, at $1244(2011))$. 
It is within this broader school choice context that tuition tax credit scholarship programs have recently emerged as the poorly-understood and barely-acknowledged, but rapidly growing, stepchild of the school choice movement.

\section{B. The History and Development of Tax Credit Scholarship Programs}

The most recent development in the school choice movement has been the move of several states to offer tuition tax credits for contributions made to student scholarship organizations ("SSOs" or "scholarship organizations" ${ }^{\text {"79) }}$ ) that, in turn, award scholarships to students who attend private schools. Theoretically, these programs offer many of the benefits of the voucher proposal advanced by Friedman-improving public schools by forcing them to compete with private schools, diversifying educational options, and, by extension, maximizing parental freedom ${ }^{80}$ - without the shortcomings of state entanglement implicating both Blaine Amendment issues and government oversight of private religious schools.

The idea of offering tax credits for moneys that end up in the hands of private schools is not itself novel. In 1979, a Note in the Harvard Law Review considered the constitutionality of a national tuition tax credit scholarship program. ${ }^{81}$ The Yale Law Journal published a Note that same year that focused on the potential that such a program would lead to the resegregation of schools. ${ }^{82}$ Some states adopted this tax credit model. "The first state to adopt deductions and credits for education expenses was Iowa[,]" which, in 1987, "allowed families earning less than $\$ 45,000$ to deduct up to $\$ 1000$ per child from their state income tax liability for education expenses. ${ }^{\circ 33}$ By 1998, the legislature had changed the law to "allow families to take a tax credit of $25 \%$ of the $\$ 1000$ spent on their children's education." ${ }^{\circ 4}$ Minnesota and Illinois adopted similar programs in the late 1990's, which courts upheld as constitutional under the

79. Different states have different terms for such organizations. I refer to them all as SSOs or scholarship organizations for the sake of uniformity. See supra note 8.

80. Viteritti, supra note 62 , at 1172.

81. See generally Note, Government Neutrality and Separation of Church and State: Tuition Tax Credits, 92 HARV. L. REV. 696 (1979).

82. See generally Note, Segregating Schools: The Foreseeable Consequences of Tuition Tax Credits, 89 YALE. L.J. 168 (1979).

83. Krista Kafer, School Choice in 2003: An Old Concept Gains New Life, 59 N.Y.U. ANN. SuRV. AM. L. 439, 445 (2003).

84. Id. 
Establishment Clause. ${ }^{85}$ Subsequently, Congressman Ron Paul proposed a federal tax credit scholarship program in $2001,{ }^{86}$ and a similar plan appeared in President George W. Bush's 2003 budget plan, ${ }^{87}$ but neither of these passed.

However, as with voucher systems, states have not rushed to implement this tax credit scholarship program model. Instead, beginning in 1997, states began to experiment with a new kind of tuition tax credit scholarship program. ${ }^{88}$ Under these programs, first implemented by Arizona, businesses or individuals who donate money to an SSO may receive a tax credit for their contribution. ${ }^{89}$ Parents wishing to send their children to private schools then apply to SSOs for scholarships. ${ }^{90}$ The SSOs then decide whether to award these scholarships to the students based on the SSOs' policies and state law. ${ }^{91}$ These schemes allow donors to gain the benefit of the tax credit regardless of whether they have children who attend public schools and, theoretically, make funds available for the private schooling of underprivileged children whose families could not make use of the tax credit system offered by states like Iowa, Minnesota, and Illinois. ${ }^{92}$ Interest in Arizona's program began to grow, and Pennsylvania and Florida each adopted versions in 2001. ${ }^{93}$ Today, twelve states have adopted this kind of tuition tax credit scholarship program, ${ }^{94}$ and in some of these states, such programs have grown considerably in scope since their inception. ${ }^{95}$ These

85. Id. at $445-46$.

86. 147 CONG. REC. E77-02 (weekly ed. Jan. 31, 2001) (statement of Rep. Paul); Family Education Freedom Act of 2001, H.R. 368, 107th Cong. (2001).

87. See The Back to School Tax Relief Act of 2002, H.R. 5193, 109th Cong. (sponsored by Rep. Bob Schaffer (R-CO)), to the House (2002).

88. Kafer, supra note 83, at 446.

89. Id.

90. Id.

91. Id. at 448 .

92. Id. at 447 .

93. Id. at 448.

94. See infra Part III.A.

95. For example, in 2011 Georgia amended its original $\$ 50$ million cap to increase with the Consumer Price Index. Act of May 11, 2011, 2011 Ga. Laws 529, 533 (codified at GA. CoDE ANN. § 48-7-29.16(f)(1) (West 2012)); Act of May 14, 2008, 2008 Ga. Laws 1108, 1111. This happened as taxpayers reached the cap for the first time in 2011, causing 2,764 applications to be denied $\$ 5.7$ million in credits. D. Aileen Dodd, Millions in Donations Returned to Taxpayers, ATLANTA J.-CONST. (Feb. 14, 2012, 6:59 PM), http://www.ajc.com/news/news/local/millions-in-donations-returned-to-taxpayers/nQRK3/. As of April 1, 2013, a pending bill in the Georgia General Assembly would increase the cap to $\$ 80$ million and adjust it according to two variables: the annual percentage change in state and local governments' gross output and the amount of unused tax credits from the previous year. H.B. 140, 152d Assemb., Reg. Sess., § 5 (Ga. 2013). 
programs have consistently withstood constitutional challenges under the Establishment Clause and state Blaine Amendments, ${ }^{96}$ and they have won the support of religious and conservative advocates for school choice as well as that of reformers focused on helping underprivileged children seeking to escape from poor public school systems. ${ }^{97}$

Despite the rapid ascent of these tuition tax credit scholarship programs, they have received relatively little attention from scholars as compared with other manifestations of the changes to the ecology of public education. Leading law and education policy casebooks do not cover tuition tax credit scholarship programs. ${ }^{98}$ Precious few law review articles discuss them, and those that do tend to (1) focus on their constitutionality, ${ }^{99}$ (2) mention them

From a political economy perspective, it is not surprising that these programs tend to metastasize as time goes on. These programs are popular among constituents-private schools and parents - who benefit from the scholarships and tax credits. They encourage their legislators to expand the programs over time, and there tends to be relatively little opposition to such incremental growth. In this sense, these programs operate as a one-way ratchet.

96. See Ariz. Christian Sch. Tuition Org. v. Winn, 131 S. Ct. 1436, 1449 (2011) (declining to give standing for want of causation and redressability because tax credits are distinct from government expenditures); Kotterman v. Killian, 972 P.2d 606, 624-25 (Ariz. 1999) (en banc) (upholding Arizona's tuition tax credit against a challenge of its federal and state constitutionality); Bush v. Holmes, 919 So. 2d 392, 408, 412 (Fla. 2006) (invalidating the state's transferring "tax money earmarked for public education to private schools" but limiting the decision only to programs involving the direct transfer of public money); Meredith v. Pence, 984 N.E.2d 1213, 1230 (Ind. 2013) (upholding Indiana's scholarship program under the state constitution). But see Griffin v. Cnty. Sch. Bd., 377 U.S. 218, 231-33 (1964) (holding that closing public schools while providing a property tax credit for donations to a segregated private school denied equal protection of the laws).

97. See Minow, supra note 20, at 829 ("[A]dvocates for poor children of color joined forces with free-market supporters and endorsers of public aid for parochial schools to seek publicly funded school choice programs that would include private religious schools."); Scott W. Somerville, The History and the Politics of School Choice, 10 GEO. MASON U. C.R. L.J. 121, 132 (1999) ("[M]ost home schoolers are for school choice plans like Arizona's, because they provide real opportunity for poor families now, without jeopardizing free minds or free markets.").

98. See generally KeRn AlEXANDER \& M. DAVID AlEXANDER, AMERICAN PUBliC SchoOl LAW (8th ed. 2011); StUART BIEGEL, EdUCATION AND THE LAW (2d ed. 2009); JohN Dayton, Education law: Principles, Policies, And Practice (2012); E. Gordon Gee \& Philip T. K. Daniel, LaW And Public Education: Cases And Materials (4th ed. 2008); Martha M. McCarthy, et al., Public School LaW (7th ed. 2013). But see Michael J. Kaufman \& Sherelyn R. Kaufman, Education Law, Policy, and Practice: Cases and MATERIALS 221 (2d ed. 2009) (contrasting vouchers with tax credits).

99. Note, Government Neutrality and Separation of Church and State: Tuition Tax Credits, supra note 81, at 714-17; Shannon E. Trebbe, Case Note, Cain v. Horne: School Choice for Whom?, 51 ARIZ. L. REV. 817, 819-21 (2009). 
as an afterthought to other elements of the school choice movement, ${ }^{100}$ or (3) discuss them in only the broadest terms. ${ }^{101}$

We can only speculate as to why the literature is notably quiet about these programs. Perhaps legal scholars have a blind spot for state legislation, particularly when any related constitutional questions are settled. ${ }^{102}$ Perhaps these programs have just developed so rapidly that commentators have not really noticed them. Or, perhaps education law and policy experts have been focused on debates that are playing out on a larger stage, like No Child Left Behind, ${ }^{103}$ Race to the Top, ${ }^{104}$ standardized testing, ${ }^{105}$ charter school funding, ${ }^{106}$ and teacher's unions. ${ }^{107}$

100. Minow, supra note 20, at 829; Somerville, supra note 97 , at 126-27.

101. Kafer, supra note 83, at 446-48.

102. The Supreme Court considered a constitutional challenge to Arizona's tuition tax credit scholarship program in the 2011 case Ariz. Christian Sch. Tuition Org. v. Winn, $131 \mathrm{~S}$. Ct. 1436, 1449 (2011). The Court held that the plaintiffs did not have taxpayer standing because the money used for the programs never passed through state coffers. Id. at 1449. This renders tuition tax credit scholarship programs effectively unreviewable.

103. No Child Left Behind Act of 2001, Pub. L. No. 107-110, 115 Stat. 1425 (2002) (codified at 20 U.S.C.A. $§ 6301-7941$ (West 2012)); see generally Regina Ramsey James, How to Mend a Broken Act: Recapturing Those Left Behind by No Child Left Behind, 45 GoNZ. L. REV. 683 (2010) (criticizing the act's faulty structure and false premise of narrowing the achievement gap through testing); James E. Ryan, The Perverse Incentives of the No Child Left Behind Act, 79 N.Y.U. L. REV. 932 (2004) (exploring incentives arising from the act to lower standards, promote segregation, and discourage good teachers from taking jobs in troubled school districts); Andrew Spitser, Comment, School Reconstruction Under No Child Left Behind: Why School Officials Should Think Twice, 54 UCLA L. REV. 1339 (2007) (arguing that reconstitution and penalization of underperforming schools raise various policy concerns).

104. American Recovery and Reinvestment Act of 2009, Pub. L. No. 111-5, § 14006, 123 Stat. 115, 283-84; Race to the Top Fund, 76 Fed. Reg. 23487 (Apr. 27, 2011); see generally Maurice R. Dyson, Are We Really Racing to the Top or Leaving Behind the Bottom? Challenging Conventional Wisdom and Dismantling Institutional Repression, 40 WASH. U. J.L. \& POL'Y 181 (2012) (assessing the effects of Race to the Top and other educational institutions while calling for greater reform); Joseph P. Viteritti, The Federal Role in School Reform: Obama's "Race to the Top", 87 NOTRE DAME L. REV. 2087 (2012) (discussing the details and policy behind Race to the Top); Shannon K. McGovern, Note, A New Model for States as Laboratories for Reform: How Federalism Informs Education Policy, 86 N.Y.U. L. REV. 1519 (2011) (justifying greater federal involvement in education due to macro-environmental changes in the world).

105. See generally Jennifer C. Braceras, Killing the Messenger: The Misuse of Disparate Impact Theory to Challenge High-Stakes Educational Tests, 55 VAND. L. REV. 1111 (2002) (opining that disparate impact theory for racial discrimination should not apply to a school's using standardized tests); William P. Quigley, Due Process Rights of Grade School Students Subjected to High-Stakes Testing, 10 B.U. PUB. INT. L.J. 284 (2001) (exploring the due process rights of students subjected to standardized testing); Stephanie Banchero, School-Test Backlash Grows, WALL ST. J. ONLINE (May 16, 2012, 10:55 AM), http://online.wsj.com/article/SB 10001424052702303505504577406603829668714.html (discussing recent resistance to standardized testing by teachers); Eric M. Johnson, Teacher 
Whatever the reason, the new tuition tax programs have not received the scrutiny they desperately deserve given their increasing popularity. This is in spite of the fact that, as we will see, the design of the programs differs dramatically from state to state in ways that have critical implications for their operation and effects.

Standoff Stokes Debate Over Standardized Tests, REUTERS (Mar. 3, 2013, 6:22 PM), http://www.reuters.com/article/2013/03/03/us-usa-education-testing-

idUSBRE92207B20130303 (detailing the national discussion about standardized testing, which has been boycotted by Seattle teachers).

106. See, e.g., 20 U.S.C. $\S \S 7221-7221$ j (2012) (regulating charter schools as a part of the No Child Left Behind Act); CoLO. REV. STAT. $\S \S 22-30.50-101$ to 22-30.5-117 (setting various requirements for charter schools in Colorado); see generally Derek W. Black, Civil Rights, Charter Schools, and Lessons to be Learned, 64 FLA. L. REV. 1723 (2012) (describing proponents of charter schools as relying primarily on ideological arguments rather than evidence); Lisa Lukasik, Deconstructing a Decade of Charter School Funding Litigation: An Argument for Reform, 90 N.C. L. REV. 1885 (2012) (deconstructing North Carolina's charter school program and proposing more direct allocations of funds); Hannah Furfaro, Senate Oks $\$ 1.4$ Million Charter School Facilities Funding Bill Over Bipartisan Opposition, AssocIATED PRESS, Mar. 29, 2013, available at http://www.idahostatesman.com/2013/03/29/2512364/senate-bill-will-help-with-charter.html (reporting that the Idaho Senate passed a bill directing state aid to charter schools); Editorial, D.C. 's Odd Resistance to More Charter Schools, WASH. Post, Feb. 14, 2013, at A18 (exploring a "misplaced concern" about the growth of charter schools in D.C.); Nina Rees, Op-Ed., Will Obama's Budget Recognize Charter Schools?, WALL ST. J., Mar. 27, 2013, at A15 (calling for greater federal support of charter schools).

107. See generally Martin H. Malin \& Charles Taylor Kerchner, Charter Schools and Collective Bargaining: Compatible Marriage or Illegitimate Relationship?, 30 HARV. J.L. \& PUB. POL'Y 885 (2007) (exploring the applicability of labor laws to charter schools); Alan Miles Ruben, The Top Ten Judicial Decisions Affecting Labor Relations in Public Education During the Decade of the 1990's: The Verdict of Quiescent Years, 30 J.L. \& EDUC. 247 (2001) (surveying major decisions during the 1990s affecting labor rights in public education); Charles J. Russo, A Cautionary Tale of Collective Bargaining in Public Education: A Teacher's Right or Tail Wagging the Dog?, 37 U. DAYTON L. REV. 317 (2012) (surveying matters of collective bargaining in public education); Steven Brill, The Teachers' Unions' Last Stand, N.Y. TIMES, May 23, 2010 (Magazine), at MM32 (detailing personal experiences with teacher unions and the effects of the changing education landscape); Neil King Jr. \& Stephanie Banchero, Unions, States Clash in Race to Top, WALL ST. J. OnLINE (Apr. 26, 2010), http://online.wsj.com/article/SB 10001424052748704388304575202470081674984.html (finding schisms between education leaders and teacher unions arising in part from Race to the Top). 


\section{The PARTICUlars OF AND PROBLEMS WITH TAX CREDIT SCHOLARSHIP PROGRAMS}

\section{A. Different States, Different Programs}

Designing a tax credit scholarship program requires policymakers to consider a host of critical factors, including, most importantly, total state expenditures on the program, the amount of the available tax credit, scholarship eligibility, and educational accountability. There is wide variation among states concerning these factors. Based on how the different states have addressed them, and according to the degree to which they restrict scholarship funding on the basis of need and impose fiscal and educational accountability requirements, I divide states' programs among three categories. To be sure, this categorization is more art than science, and reasonable people may disagree as to how particular programs should be categorized. I provide sufficient information about each state's approach for readers to make their own assessment in this regard. In any event, the purpose of categorizing programs in this manner is simply to provide a framework for thinking about these programs and to demonstrate that there are several variables that interact to produce vastly different programs and practical effects. Given the wide variation among programs, they are best understood as spectral rather than categorical.

1. Programs with Robust Eligibility Requirements and Accountability Measures: Alabama, Florida, Louisiana, Indiana, Iowa, Virginia

Tax credit scholarship programs that fall into this category are those that (1) significantly limit eligibility for scholarships to students based on their household income or assignment to poor public schools, and (2) impose standardized testing requirements. However, there is substantial variation among even those programs that meet these requirements.

\section{a. Alabama}

Alabama, the most recent state to have adopted a tax credit scholarship program, ${ }^{108}$ introduced two different schemes to provide for school choice, both using tax credits and both designed primarily to help families of limited means who are assigned to failing public schools. The first element

108. Chappell, supra note 6. 
of the program is a direct tax credit that appears to function something like the voucher program proposed by Milton Friedman and the tax credit programs discussed in the Harvard Law Review and Yale Law Journal in the late 1970s. ${ }^{109}$ This aspect of the program is beyond the scope of this Article, though it bears noting that it is the most extensive and generous of all direct tax credit or voucher programs in the country. At the same time, Alabama introduced a tax credit scholarship program for contributions to scholarship organizations. ${ }^{110}$

Alabama's program budgets a total of $\$ 25$ million to its tax credit scholarship program. ${ }^{111}$ Under the program, individual taxpayers may claim a dollar-for-dollar tax credit of up to $50 \%$ of their tax liability, not to exceed $\$ 7,500$, for a contribution to a scholarship organization. ${ }^{12}$ Corporations may claim the tax credit for $50 \%$ of their contribution, up to $50 \%$ of their total tax liability. ${ }^{113}$ The credit can be carried forward for up to three years. ${ }^{114}$

Each scholarship organization must spend a percentage of its scholarship expenditures equal to the percentage of low-income eligible students in the county in which the organization spends the majority of its scholarship resources. ${ }^{115}$ Further, $75 \%$ of first-time scholarship recipients must not have been continuously enrolled in a private school during the previous year, ${ }^{116}$ and scholarships must be portable from school to school by students during the school year. ${ }^{117}$ Perhaps most important, only students who (1) would otherwise attend a failing public school $^{118}$ and (2) are members of households whose total income does not exceed $150 \%$ of the median state household income are eligible to receive the scholarships. ${ }^{119}$

Finally, in order to maintain transparency and accountability, scholarship organizations and participating schools are required to report a variety of information to the state demonstrating compliance ${ }^{120}$ and, further,

109. ALA. CODE § 16-6D-8 (2013); Friedman, supra note 25, at 123; Robert McClendon, Alabama Accountability Act Includes What Amounts to a School Voucher Program, Choice Advocates Say, AL.COM (Mar. 6, 2013, 6:00 AM), http://blog.al.com/wire/2013/03/accountability_act_includes_wh.html.

110. ALA. CODE $\S 16-6 D-9$ (2013).

111. Id. $\S 9(\mathrm{a})(3)$.

112. Id. $\$ 9(\mathrm{a})(2)$.

113. Id. $\S 9(\mathrm{a})(3)$.

114. Id. $\S 9(\mathrm{a})(4)$.

115. $I d . \S 9(\mathrm{~b})(1)(\mathrm{f})$.

116. Id. $\S 9(\mathrm{~b})(1)(\mathrm{g})$.

117. Id. $\S 9(\mathrm{~b})(1)(\mathrm{i})$.

118. Id. $\S 9(\mathrm{~b})(1)(\mathrm{m})$

119. Id. § 4(2)(a).

120. Id. § 9(b)(1)(j). 
participating private schools must administer standardized tests to students receiving scholarships. ${ }^{121}$

In sum, although Alabama's program does not altogether restrict scholarship eligibility to those who would typically be identified as underprivileged, it has several methods in place to ensure that many or most of the scholarships are directed to those who could not otherwise afford private school and are ill-served by the public school system. In addition, Alabama's program appears to have effective means of ensuring accountability and tracking the program's success.

\section{b. Florida}

Florida allows only corporations to receive a dollar-for-dollar tax credit for contributions to scholarship organizations. ${ }^{122}$ In 2012, total tax credits could equal no more than $\$ 229$ million, but this limit is flexible and can rise each year. ${ }^{123}$ Scholarships are limited to students who qualify for the free or reduced-price lunch program and meet certain other criteria. ${ }^{124}$ Additionally, scholarship recipients between third and tenth grade must take standardized tests. $^{125}$

\section{c. Louisiana}

Louisiana's tax credit scholarship program is new for $2013 .{ }^{126}$ Under Louisiana law, any taxpayer may receive a dollar-for-dollar tax credit for contributions to scholarship organizations. ${ }^{127}$ The state imposes no limits on the total value of credits that may be claimed. ${ }^{128}$ To be eligible for a scholarship, a student's household income must be no more than $250 \%$ of the federal poverty level, and the student must be entering kindergarten, must have attended public school the previous year, or must have received a scholarship under this program the previous school year. ${ }^{129}$ Further, donors are prohibited from designating scholarships for a particular student or school (though they may designate contributions for students with

121. Id. § 9(c)(2)(a)(1).

122. Fla. StAT. § 212.1831 (2012); Fla. AdMin. CODE ANN. r. 12-29.002(5) (2013).

123. Fla. STAT. $§ 1002.395(5)(a)(2012)$.

124. Id. $\$ 1002.395(3)$.

125. Id. $\$ 1002.395(8)(\mathrm{c})(2)$.

126. See H.B. 969 § 2, 2012 Leg., 38th Reg. Sess. (La. 2012); 2012 La. Acts 17 §.

127. LA. ReV. Stat. AnN. § 47:6301(A)(1) (2012).

128. Id.

129. Id. § 47:6301(B)(3). 
disabilities), ${ }^{130}$ and participating private schools are required to administer standardized tests to participating students. ${ }^{131}$

\section{d. Indiana}

Indiana allows individuals and corporations ${ }^{132}$ to receive a tax credit for contributions to scholarship organizations. ${ }^{133}$ The amount of the credit is not limited, ${ }^{134}$ but it is only worth $50 \%$ of the contribution. ${ }^{135}$ Further, the total amount of tax credits that may be awarded by the state in a fiscal year is capped at a relatively paltry $\$ 7.5$ million. ${ }^{136}$ To be eligible for a scholarship, students must have a household income of no more than $200 \%$ of the qualifying amount for the free or reduced-price lunch program and either be starting kindergarten or have been previously enrolled in a public school. ${ }^{137}$ Finally, private schools must administer standardized tests to all students in the school. ${ }^{138}$

Thus, Indiana's program is restrictive in several respects. The total amount the state spends on the program is extremely limited; donors do not receive dollar-for-dollar credits; scholarship eligibility is means-tested; and testing requirements allow for assessment of the educational effects of the program.

\section{e. Iowa}

Iowa's program is substantially similar to Indiana's. The state allows individuals and corporations a tax credit equal to $65 \%$ of their total contributions made to a school tuition organization during the tax year. ${ }^{139}$ Although there is no limit on the amount of a credit an individual can claim, ${ }^{140}$ there is a statewide tax credit cap of $\$ 8.75$ million per year until 2014 , and a cap of $\$ 12$ million per year thereafter. ${ }^{141}$ No more than $25 \%$ of the tax credits may go to corporations. ${ }^{142}$

130. Id. $\S 47: 6301(\mathrm{~A})(3)$.

131. Id. § 47:6301(B)(2)(a)(ii).

132. IND. CODE $\S 6-3.1-30.5-6$ (2012).

133. Id. § 6-3.1-30.5-7.

134. See id.

135. Id. § 6-3.1-30.5-8.

136. Id. $\S 6-3.1-30.5-13$.

137. Id. $\S 20-51-1-4.5$.

138. Id. § 20-51-1-4.7.

139. IOWA CODE $\S 422.11 \mathrm{~S}(1)$ (2013).

140. See id.

141. Id. $\S 422.11 \mathrm{~S}(7)(\mathrm{a})(2)$.

142. IOWA ADMIN. CODE r. 701-52.38(1) (2013). 
Scholarship organizations must allocate at least $90 \%$ of their annual revenue in the form of scholarships. ${ }^{143}$ Donors are prohibited from designating scholarship recipients, ${ }^{144}$ and to receive a scholarship, a student's family income must be no more than $300 \%$ of the federal poverty guideline. ${ }^{145}$ Finally, participating schools must administer standardized tests to all students. ${ }^{146}$

\section{f. Virginia}

Virginia awards corporations and individuals tax credits equal to $65 \%$ of contributions made to scholarship organizations. ${ }^{147}$ Individual credits are issued only for the first $\$ 125,000$ in value of contributions in a given year, but there is no cap on how much a business can receive in tax credits. ${ }^{148}$ Total state expenditures on the program are capped at $\$ 25$ million per year. $^{149}$

The program limits scholarship eligibility to students whose family income is not greater than $300 \%$ of the federal poverty level, ${ }^{150}$ and to students with disabilities whose family income is not greater than $400 \%$ of the federal poverty level. ${ }^{151}$ In addition, participating private schools must administer standardized tests to students who receive scholarships. ${ }^{152}$

2. Programs with Moderate Eligibility Requirements and Accountability Measures: Pennsylvania, Rhode Island, Oklahoma, New Hampshire

Programs in this category are those that are means-tested in some way but that do not impose standardized testing requirements. As such, it is difficult for policymakers or experts to assess the relative success of these programs in improving educational quality for students who receive funding.

143. IOWA CODE $\S 422.11 \mathrm{~S}(5)(\mathrm{c})(1)(2013)$.

144. Id. $\S 422.11 \mathrm{~S}(2)(\mathrm{b})$.

145. Id. $\S 422.11 \mathrm{~S}(5)(\mathrm{a})$.

146. See id. $\S 422.11 \mathrm{~S}(5)(\mathrm{b})$ (requiring accreditation for qualified schools); IowA ADMIN. CODE r. 281-12.8(1)(f) (2013) (mandating schools to test students and report results).

147. VA. CODE ANN. § 58.1-439.26(A) (2013).

148. Id.

149. Id. § 58.1-439.26(B)(1).

150. Id. § 58.1-439.28(C).

151. Id. § 58.1-439.25.

152. Id. § 58.1-439.28(D). 


\section{a. Pennsylvania}

Pennsylvania allows corporations to claim a tax credit equal to $75 \%$ for a one-year contribution, ${ }^{153}$ or $90 \%$ for a two-year contribution. ${ }^{154}$ As of $2013-$ 2014 , the maximum allowable credit for any corporation is $\$ 750,000,{ }^{155}$ and the total expenditures permitted by the state are $\$ 100$ million. ${ }^{156}$ In addition, corporations can receive a dollar-for-dollar tax credit for the first $\$ 10,000$ contributed to pre-kindergarten scholarship organizations and a $90 \%$ tax credit for any amount thereafter, ${ }^{157}$ with total state expenditures capped at $\$ 10$ million of the $\$ 100$ million total allowable credits. ${ }^{158}$

Beginning July 1, 2013, students with household incomes of $\$ 75,000$ or less - with an allowance of $\$ 15,000$ for each additional dependent - are eligible to receive scholarships. ${ }^{159}$ Scholarships cannot be limited by the scholarship organization to only one school. ${ }^{160}$ Finally, there is no requirement for participating private schools to administer standardized tests.

\section{b. Rhode Island}

Rhode Island's program only offers tax credits for contributions by corporations. ${ }^{161}$ The credit is worth $75 \%$ of the contribution, ${ }^{162}$ or $90 \%$ if the corporation agrees to match the contribution for two consecutive years. ${ }^{163}$ Each corporation can claim a maximum credit of $\$ 100,000,{ }^{164}$ and the state caps total expenditures at a paltry $\$ 1.5$ million. ${ }^{165}$

Scholarship eligibility is limited to students with a household income of less than $250 \%$ of the federal poverty guideline. ${ }^{166}$ In addition, donors are prohibited from designating particular students or schools as scholarship

153. 72 Pa. Cons. StAT. ANN. § 8705-F(a) (West 2012).

154. Id. § 8705-F(b).

155. Id. $\S 8705-\mathrm{F}(\mathrm{d})$.

156. Id. $\S 8706-\mathrm{F}(\mathrm{a})(1)$.

157. Id. $\S 8705-\mathrm{F}(\mathrm{c})$.

158. Id. $\S 8706-\mathrm{F}(\mathrm{a})(2)(\mathrm{iii})$.

159. Id. $\S 8702-\mathrm{F}$.

160. $I d$.

161. R.I. GEN. LAWS § 44-62-1 (2012).

162. Id. $\S 44-62-4(\mathrm{c})$.

163. Id. § 44-62-4(e).

164. Id. $\S 44-62-5(\mathrm{a})$.

165. Act of July 3, 2013, ch. 144, art. 9, sec. 14, 2013 R.I. Pub. Laws (amending R.I. GEN. LAWS ANN. § 44-62-3(b)).

166. R.I. GEN. LAWS § 44-62-2(1). 
recipients. ${ }^{167}$ However, participating private schools are not required to administer standardized tests. ${ }^{168}$

\section{c. Oklahoma}

Oklahoma's program allows individuals and corporations to claim a tax credit worth $50 \%$ of a contribution, ${ }^{169}$ or $75 \%$ if, after making a contribution, the taxpayer makes a commitment to contribute the same amount for two additional consecutive years. ${ }^{170}$ The maximum credit for individuals is $\$ 1,000$ ( $\$ 2,000$ married couples filing jointly) and $\$ 100,000$ for corporations. ${ }^{171}$ Total state expenditures cannot exceed $\$ 1.75$ million in credits for individuals and an additional $\$ 1.75$ million for corporations. ${ }^{172}$

Students with household incomes at or below $300 \%$ of the standard to qualify for a free or reduced price lunch and those zoned for failing public schools are eligible for scholarships. ${ }^{173}$ The law imposes no testing requirements for participating private schools. ${ }^{174}$

\section{d. New Hampshire}

New Hampshire offers corporations tax credits worth $85 \%$ of a contribution to a scholarship organization, though no single corporation is permitted to receive a tax credit for more than $10 \%$ of the aggregate amount of tax credits allowed in a given year. ${ }^{175}$ Total state expenditures on these tax credits was capped at $\$ 3.4$ million in the program's first year and $\$ 5.1$ million in the second, and if certain conditions are met, the cap may increase by $25 \%$ in subsequent years. ${ }^{176}$

Any student who attended a public school in the prior year is eligible to receive a scholarship, while all students with household incomes less than $300 \%$ of the federal poverty guidelines are also eligible. ${ }^{177}$ Donors are

167. Id. § 44-62-2(9).

168. See id. §44-62-2(5) (defining qualified schools as those that satisfy the requirements prescribed for nonpublic schools); id. §16-22-9 (establishing standardized testing for public schools and allowing standardized testing upon request by nonpublic schools).

169. OKLA. STAT. tit. 68, § 2357.206(B)(1) (2012).

170. Id. § 2357.206(C)(2).

171. Id. § 2357.206(B)(1).

172. Id. § 2357.206(B)(2).

173. Id. § 2357.206(F)(1).

174. See id. $\S 2357.206(\mathrm{~F})(5)$.

175. N.H. REV. STAT. ANN. § 77-G:3 (2013).

176. Id. $\$ 77-\mathrm{G}: 4$.

177. Id. § 77-G:1(VIII). 
prohibited from designating scholarships for particular students. ${ }^{178}$ There are no testing requirements. ${ }^{179}$

3. Programs with Few Eligibility Requirements and Accountability Measures: Arizona, Georgia

The programs in this category are those that neither means-test scholarship eligibility nor impose testing requirements.

\section{a. Arizona}

Arizona was the first state to offer a $100 \%$ tax credit for contributions for scholarship program. ${ }^{180}$ Under Arizona law, individuals may receive a dollar-for-dollar tax credit of $\$ 500$ ( $\$ 1000$ for married couples filing jointly), ${ }^{181}$ while there is no limit for credits corporations may obtain. ${ }^{182}$ Credits may be carried forward for five years. ${ }^{183}$ The state limited credits to $\$ 17.28$ million in $2010,{ }^{184}$ with the cap increasing by $20 \%$ each year. ${ }^{185}$

Arizona's program does not means-test eligibility for scholarship recipients. ${ }^{186}$ However, corporate contributions (as opposed to contributions by individuals) must primarily be spent on scholarships for low-income students entering kindergarten at schools that provide services for disabled students or those students who attended public school during the previous year. ${ }^{187}$ The law also prohibits donors from designating their contributions for a dependent of the donor, ${ }^{188}$ and scholarship organizations cannot limit

178. Id. $\S 77-\mathrm{G}: 3$.

179. Because New Hampshire's program is available to all public school students and there are no testing requirements, reasonable people may conclude that it is best assigned to category 3. However, I have chosen to place it in category 2 because the tax credit is not dollar-for-dollar, is limited to corporations, and the program is means-tested for students not previously enrolled in public schools.

180. H. Lillian Omand, Note, School Choice Legislation: A Supply-Side Market Effects Analysis, 20 J.L. \& POL. 77, 88 (2004).

181. ARIZ. REV. STAT. § 43-1089(A) (2012).

182. Id. § 43-1183(B).

183. Id. $\S 43-1183$ (E) (applying to corporate contributions); id. $\S 43-1089$ (D) (applying to individual contributions).

184. Tuition Tax Credits, NAT'L Conf. OF STATE Legislatures, http://www.ncsl.org/issues-research/educ/school-choice-scholarship-tax-credits.aspx (last visited Sept. 08, 2013).

185. ARIZ. REV. STAT. § 43-1183(C)(1) (2012).

186. Id. § 43-1603(D).

187. Id. $\S 43-1504(\mathrm{~A})$.

188. Id. $\S 43-1089(\mathrm{~F})$; see also id. $\S 43-1603(\mathrm{~B})(4)$ (prohibiting scholarship organizations from allowing donors to designate beneficiaries). 
availability of scholarships to students of only one school. ${ }^{189}$ Finally, the law mandates that the scholarship organization report substantial information, ${ }^{190}$ including aggregate information about the income of scholarship recipients, ${ }^{191}$ but, it does not impose any testing requirements.

Thus, Arizona's tax credit scholarship program imposes few restrictions on who may receive scholarships and includes no educational accountability standards, though it does provide a means of assessing who receives the scholarships.

\section{b. Georgia}

Georgia's program allows tax credits to total $\$ 58$ million annually. ${ }^{192}$ Individuals may receive dollar-for-dollar tax credits of up to $\$ 1000$ for contributions (\$2500 if married and filing jointly), ${ }^{193}$ while corporations may receive up to $75 \%$ of their total tax liability in dollar-for-dollar tax credits. ${ }^{194}$ Credits may be carried forward for up to five years. ${ }^{195}$

All students in Georgia are eligible to receive scholarships under the program, so long as they are or were previously enrolled in a public school or entering kindergarten or first grade,${ }^{196}$ but donors may not designate their dependents as beneficiaries of their contributions. ${ }^{197}$ Additionally, although the law imposes some perfunctory reporting requirements, none of them require scholarship organizations or participating private schools to provide any information about the income levels of recipients. ${ }^{198}$ Likewise, participating private schools are not required to administer standardized tests.

In short, Georgia's program imposes the fewest restrictions on who may receive scholarship funding, effectively leaving that question up to scholarship organizations alone to decide. Additionally, it provides

189. Id. $\S 43-1503(\mathrm{~B})(2)$ (applying to organizations receiving corporate contributions); $i d$. $\S 43-1603(\mathrm{~B})(2)$ (applying to organizations receiving individual contributions).

190. Id. § 43-1506 (applying to organizations receiving corporate contributions); id. §431604 (applying to organizations receiving individual contributions).

191. Ariz. DeP'T of Revenue, MANuAl FOr SCH. Tuition Orgs. 6 (2013), available at http://www.azdor.gov/LinkClick.aspx?fileticket=7yB6sLip-0k\%3D\&tabid=136.

192. GA. CODE $\S 48-7-29.16$ (f)(1) (2013).

193. Id. § 48-7-29.16(b).

194. Id. $\$ 48-7-29.16$ (c).

195. Id. § 48-7-29.16(e).

196. Id. § 20-2A-1(1).

197. Id. \$ 48-7-29.16(d).

198. Id. § 20-2A-3; GA. COMP. R. \& REGS. 560-7-8.47(5)(c) (2013). 
essentially no accountability measures or means of assessing its educational impact.

\section{B. The Justification/Effect Mismatch and the Potential for Abuse}

Any assessment of the value of these programs is dependent, in part, on identifying their purposes. For instance, a tax credit scholarship program that is adopted with the purpose of providing school choice for all parents cannot be assessed the same way as one adopted to offer a means for students to escape poor public schools when they would not otherwise be able to afford them. Similarly, one that is intended to facilitate the ability of parents to direct the education of their children must be judged by different measures than one with the goal of improving educational achievement. ${ }^{199}$

At the very least, however, it is fair to measure these programs according to the justifications their supporters articulate when advocating their passage. One might reasonably expect that the programs with greater restrictions on scholarship recipients - in other words, those that are meanstested or tied to public school failure-were intended to improve educational opportunities for relatively underprivileged students, whereas those with fewer restrictions were more broadly intended to expand school choice for everyone. Likewise, one might surmise that those programs that impose testing requirements were motivated by a desire to improve educational outcomes, whereas those without testing requirements were simply intended to expand access to school choice.

But these reasonable expectations would be wrong. Indeed, advocates of tax credit scholarship programs in all states-including those with programs that impose little by way of eligibility restrictions or educational accountability measures - expressly pushed for their passage on the grounds that they would help those otherwise without access to education alternatives to opt out of poor public schools and receive better educations.

Consider the case of Georgia, whose program imposes the least restrictions of any state on scholarship eligibility and no educational accountability measures. Former State Senator Eric Johnson, who introduced the bill in the state senate, insisted that the bill would help those children "who most need it." 200 He further asserted that scholarship organizations would not likely give scholarships to the relatively wealthy ${ }^{201}$

199. I later address the question of educational achievement. See supra Part III.D.

200. Video Recording: Georgia Senate Proceedings, Apr. 1, 2008 at 1:37:00.

201. Id. at 1:39:31. 
and that the bill would assist those children who hoped to "better their education and prepare themselves for college."202 More broadly, the bill's supporters viewed the program as a "plan to help lower-income schoolchildren get out of shoddy public schools," ${ }^{203}$ and it was portrayed as a measure to "provide a choice between public and private schools to children whose parents cannot afford it."204

By these measures, Georgia's tax credit scholarship program is an abject failure, due largely to its design. First, because there are no testing requirements, there is simply no way of assessing the relative quality of the education that scholarship awardees receive when compared to what they would receive from their assigned public school. Further, because there are no substantive reporting requirements, we have no real means of assessing who receives scholarship funding. In fact, there is scant evidence that any children who would not otherwise have been able to attend private schools in Georgia have done so thanks to the program. ${ }^{205}$

It appears that the real effect of Georgia's program is to provide an alternative funding source for schools, whether for students who otherwise would have received scholarships made possible by tax-deductible charitable contributions or cross-subsidization by other students' tuition fees or, even more troublingly, to students who would have otherwise paid full tuition. Indeed, according to investigative reports by media and nonprofit organizations, some schools essentially guaranteed to donors that their dependents or designees would receive scholarships equal to the value of their contribution to the scholarship organization associated with the school. In other words, schools and associated scholarship organizations would simply treat contributions as an alternative means of paying tuition,

202. Id. at 1:10:43.

203. Ben Smith, Legislature 2008: Tax Breaks for Groups that Send Kids to Private School $O K ' d$, ATLANTA J.-CONST., Mar. 12, 2008, at B3.

204. Delon Pinto \& Wade Walker, Elementary and Secondary Education: Amend Titles 20 and 48 of the Official Code of Georgia Annotated Reading, Respectively to Education and Revenue Taxation, so as to Provide for a Program of Educational Improvement; Provide for Student Scholarship Organizations; Provide for an Income Tax Credit with Respect to Qualified Education Expenses; Provide for an Income Tax Exclusion with Respect to Certain Scholarship Amounts; Provide for Powers, Duties, and Authority of the State Revenue Commissioner with Respect to the Foregoing; Provide for Related Matters; Provide an Effective Date; Provide for Applicability; Repeal Conflicting Laws; and for Other Purposes, 25 GA. ST. U. L. REV. 73, 82 (2008).

205. See Stephanie Saul, Public Money Finds Back Door to Private Schools, N.Y. TIMES, May 21, 2012, at A1 (concluding "that most of the students receiving the scholarships [in Georgia] had not come from public schools" because "private school enrollment increased by only one-third of one percent in the metropolitan counties that included most of the private schools in the scholarship program"). 
thus enabling and encouraging what should be viewed as tax fraud. This is despite the fact that donors are technically prohibited under the law from designating their own dependents as beneficiaries. There has simply been no effort or means of enforcing even this most basic restriction.

Finally, the only measure in the law that places any kind of limits on scholarship eligibility-namely, the requirement that recipients have previously enrolled in public school ${ }^{206}$ - has also been gamed by Georgia parents who would simply register their children in local public schools without ever sending them. ${ }^{207}$

Frankly, each of these consequences was entirely predictable by anyone who read the bill carefully and noted its lack of controls and accountability measures. ${ }^{208}$ We can only speculate as to whether these effects are due to innocent mistakes in designing the program or to an intentional effort to channel money to those who already have access to private schools while cloaking it in altruistic-sounding justifications. What is evident, however, is that, depending on how carefully crafted and regulated a program is, there is a potential mismatch between the justifications offered for it and its actual effects. Further, such programs may be subject to substantial abuse.

\section{Do Tax Credit Scholarship Programs Improve Educational Outcomes?}

Perhaps the true test for whether tax credit scholarship programs are successful is whether they demonstrably improve educational outcomes for those who receive scholarships under them.

To be sure, some may disagree as to whether this is, in fact, the relevant question. Some may argue that the privatization of education brings with it social costs such that even if those who receive SSO scholarships receive better educations, something important is lost with respect to the socialization and civic benefits of public education. ${ }^{209}$ This view is

206. GA. CODE § 20-2A-1(1) (West 20132).

207. Steve Suitts \& Katherine DunN, Ga. DeP'T of Revenue, A Report AND

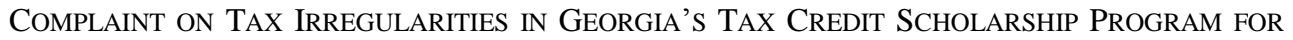
Private Schools 20 (2013); James Salzer, Tuition Loophole Exploited, AtLANTA J.-Const., Aug. 9, 2009, at B1.

208. Indeed, opponents of the bill expressed serious concerns and reservations about the lack of means-testing and other restrictions. See Pinto \& Walker, supra note 204, at 77-78 (noting Georgia Senator Emanuel Jones's concern about the possibility that scholarships could go to students formerly enrolled at private schools).

209. See John Dayton \& Carl Glickman, American Constitutional Democracy: Implications for Public School Curriculum Development, 69 PEABODY J. OF EDUC., at 62, 62-80 (1994). 
essentially a value judgment, perhaps not subject to quantification. An alternative value judgment may be that regardless of the measurable educational benefits of private school tax credit scholarship programs, they are beneficial because they provide parents alternative choices concerning how to educate their children, itself a worthy goal. For example, a private school that may offer a worse education may nonetheless be judged preferable by a parent who views the social or religious environment as paramount.

Further, even those who believe that measuring the practical effects of tax credit scholarship programs is a central part of assessing their value, some may maintain that whether the scholarships improve educational outcomes for those who receive scholarships offers an incomplete picture. After all, there may be negative (or positive) externalities for those who do not receive them - that is, those who remain in public schools or who attend private schools without receiving SSO scholarships. ${ }^{210}$ Others may argue that standardized achievement tests upon which such comparisons are likely to be based offer poor gauges of educational success. These are objections to the methodology of assessment rather than to the idea of assessment itself. However, because scholarship programs' educational effects do not lend themselves to obvious alternative means of appraisal, these arguments may function as a practical matter as objections to the idea of assessment.

These deontological and methodological objections notwithstanding, most would probably agree that measuring the effects of tax credit scholarship programs on those who receive SSO scholarships provides at least some useful information. Unfortunately, there has been precious little research on this specific question, perhaps due to the novelty of tax credit scholarship programs and the difficulty of undertaking such research, including that many states do not require SSOs to disclose the identity of or individualized demographic data concerning scholarship recipients. The

210. See Walter Feinberg, The Dialectic of Parent Rights and Societal Obligation: Constraining Educational Choice, in SCHOOL CHOICE POLICIES AND OuTCOMES: EMPIRICAL AND Philosophical Perspectives 219, 230 (Walter Feinberg \& Christopher Lubienski eds., 2008) (opining that decreased tax funds from increased private schooling will reduce the quality of public education); see also Cassandra M.D. Hart \& David Figlio, Does Competition Improve Public Schools?, 11 EDUC. NEXT, Winter 2011, at 74 (2011), available at http://educationnext.org/does-competition-improve-public-schools/ (reflecting on the ambiguity of private school effects given that competition could either incentivize changes to improve results or siphon funds and the most involved families); Caroline Minter Hoxby, Do Private Schools Provide Competition for Public Schools? 31 (Nat'l Bureau of Econ. Research, Working Paper No. 4978, 1994) (using regression analysis to conclude that competition from private schools benefits performance at public schools, which could be attributable to several alternative explanations). 
best that can be done is to extrapolate from studies that compare private school and public school student academic performance. And here, the limited evidence is mixed at best.

The seminal study is James Coleman's High School Achievement: Public, Catholic, and Private Schools Compared. ${ }^{211}$ There, and in a followup article, Public and Private High Schools: The Impact of Communities, ${ }^{212}$ Coleman analyzed national data to conclude that private schools produced better results on standardized tests, especially for historically disadvantaged minority students. ${ }^{213}$

Since then scholars have criticized Coleman's methodology ${ }^{214}$ and have found that private schooling tends to have a weak or statistically insignificant effect on academic achievement for the general population. ${ }^{215}$ In fact, students in the fastest-growing segment of private schools, conservative Christian schools, "are almost a year behind their public school counterparts." 216 There is a consensus, however, that a significant, positive private school effect exists for low-income minorities. ${ }^{217}$ Given

211. James S. Coleman, Thomas Hoffer \& Sally Kilgore, High School ACHIEVEMENT: Public, CATHOlic, ANd PRIVATE SCHOOls COMPARED (1982).

212. James S. Coleman \& Thomas Hoffer, Public and Private High Schools: The IMPACT OF COMMUNITIES (1987).

213. Mark Berends, Marisa Cannata \& Ellen B. Goldring, School Choice Debates, Research and Context: Toward Systematic Understanding and Better Educational Policy, in School Choice AND School Improvement 3, 4-5 (Mark Berends, Marisa Cannata \& Ellen B. Goldring eds., 2011).

214. See id. at 5 (stating that the most common criticism was for Coleman's failing to eliminate selection bias); Christopher Lubienski, The Politics of Parental Choice: Theory and Evidence on Quality Information, in SCHOOL CHOICE POLICIES AND OUTCOMES: EMPIRICAL AND PhilosophicAl PERSPECTIVES 99, 108 (Walter Feinberg \& Christopher Lubienski eds., 2008) (critiquing methodologies of studies finding positive effects for misrepresenting other research and implying but not showing causation).

215. See Berends, supra note 213, at 4-5 (finding that subsequent studies have found at most small effects on student test scores, but larger effects on graduating and college enrollment); RonAld G. CORWIN \& E. JosePh SCHNEIDER, THE SCHOOL CHOICE HoAX: FiXING AMERICA's SCHOOLS 23-25 (2005) (arguing that studies claiming to show a significant positive effect exaggerate the results); Maureen T. Hallinan \& Warren N. Kubitschek, School Sector, School Poverty, and the Catholic School Advantage, 14 CATHOLIC EDUC. 143, 166 (2010) (opining that the advantage of Catholic schools is less clear in subsequent studies given that progress in Catholic schools' test scores mimic public schools' gains, despite better performance for students in Catholic middle schools).

216. Lubienski, supra note 214 , at 106.

217. See CORWIN \& SCHNEIDER, supra note 215 , at 24 (noting that a randomized study found improved results for African American students); see also Paul E. Peterson, William G. Howell, Patrick J. Wolf \& David E. Campbell, School Vouchers: Results from Randomized Experiments, in THE ECONOMICS OF SCHOOL CHOICE 107, 131 (2002) (concluding from an analysis of voucher programs in three cities that there were effects "only on the average test 
this, it makes sense to design tax credit scholarship programs in a way that will benefit these low-income minorities.

\section{BEST PRACTICES FOR TAX CREDIT SCHOLARSHIP PROGRAMS}

Because tax credit scholarship programs may suffer from a serious mismatch between their purposes and their effects and are potentially subject to substantial abuse, and because their educational value is not proven, states should be cautious in designing them. This Part develops a framework that states should incorporate when they adopt such programs. In recognition of the fact that different states may have different needs and goals for such programs and that there is no one-size-fits-all approach, this Part offers different options for states to consider within the broader rubric of scholarship programs.

\section{A. Scholarship Eligibility}

The single most important question for states to consider in designing a tax credit scholarship program is what the eligibility criteria are for students to receive scholarships. The options here are essentially infinite, from allowing all students to receive scholarships at the discretion of the scholarship organization on one end of the spectrum, all the way to restricting scholarships to the most destitute of students on the other. In a sense, this is the central policy question that requires states to articulate their programs' purpose. However, because all states have indicated that a-or the-core goal of their programs is to help needy children escape poor public schools, it is fair to take the states at their word and consider various means of achieving this aim. Further, because the evidence suggests that private schooling is most likely to assist the most needy, a strong normative argument can be made that this is the most reasonable use of funds that have been diverted from the public fisc.

Therefore, states should not open eligibility to all students at the discretion of scholarship organizations. In addition to undermining the

performance of African American students," who after two years scored $6.3 \%$ higher on the Iowa Tests of Basic Skills than African Americans remaining in public school); see also Kafer, supra note 83, at 454-55 (discussing government and academic studies finding significant academic gains for African American students); William N. Evans \& Robert M. Schwab, Finishing High School and Starting College: Do Catholic Schools Make a Difference?, 110 Q.J. ECON. 941, 971 (1995) (finding that attending Catholic schools increases the likelihood of graduating and attending college, especially for urban students). 
fundamental purpose of the program, doing so inevitably invites scholarship organizations and associated private schools to engage in or enable questionable or even fraudulent behavior by allowing relatively wealthy individuals to funnel tuition costs for their own children through these programs.

Once states commit to limiting scholarship eligibility in some way, the more difficult question, of course, is how to do so. Thus far, among the states that have limited eligibility, there have been three different methods of doing so, used either individually or in combination. None of these approaches is perfect.

One approach has been to means-test eligibility — that is, to tie eligibility to students' household income. States that have adopted this approach have limited eligibility to students with family incomes ranging from $250 \%$ to $400 \%$ of the federal poverty guideline. ${ }^{218}$ The purpose of this limitation is, self-evidently, to direct scholarships to those students who could not otherwise afford to attend private school. It may have the additional effect of eliminating or reducing the problem of parents directing their own contributions to their own children's benefit, because households with such limited income are unlikely to be able to afford to contribute to scholarship organizations in the first place. Consequently, this limitation is the most powerful means of limiting scholarship eligibility.

However, if this is the only limitation imposed by a tax credit program, it suffers from problems of potential overinclusion and underinclusion. On the one hand, some children with access to excellent public schools will qualify for scholarships. This may be acceptable to some states and policymakers, but for those who see a tax credit program as a means of providing alternatives to poor public schools in particular, means-testing the program is insufficient. On the other hand, because private school tuition tends to be quite expensive - especially at the best schools - these income limits might be far too low. For example, two times the federal poverty level for a family of four is an annual income of $\$ 47,100 .^{219}$ A family with income substantially greater than this would be far from wealthy and would not be able to afford most private schools, yet states that set scholarship eligibility

218. Compare R.I. GEN. LAWS § 44-62-2(1) (2012) (limiting scholarship availability to families earning less than $250 \%$ of the federal poverty guideline) with VA. CODE ANN. $§ 58.1$ 439.25 (2013) (increasing the cap to $400 \%$ of the poverty level for disabled students).

219. See Annual Update of the HHS Poverty Guidelines, 78 Fed. Reg. 5182, 5183 (Jan. 24, 2013) (providing a $\$ 23,550$ poverty threshold for a family of four in the contiguous United States). 
at twice the federal poverty level would prohibit these children from receiving funding. ${ }^{220}$

An alternative (and sometimes complementary) approach, which responds to the problems of overinclusion and underinclusion associated with means-testing, has been to limit scholarship eligibility to students zoned for failing or poorly performing public schools. The effect of this limitation is to direct scholarships to students who might otherwise be deprived of access to adequate schools. This approach also has problems of overinclusion and underinclusion. First, this approach is underinclusive because it ties scholarship eligibility to the success of a school as a whole rather than to the success of a particular child in a given public school. Thus, a student who performs poorly in a public school that is rated satisfactory would be ineligible even if her public school is failing her and she would excel in a different schooling environment. Second, if this restriction is adopted without more, families with substantial means who happen to reside in failing public school zones, and who may well send their children to private schools even without the assistance of scholarships, are equally eligible for scholarships as poor students.

Some states have adopted a third approach to address the problem of channeling funding to children who would attend private school in any case by restricting scholarship eligibility to students who previously attended public schools. In effect, this requirement assures that scholarships will not be directed to parents who would have sent their children to private schools even without the scholarships made available by this program. ${ }^{221}$ However, programs that incorporate this requirement tend to have an important exception: students entering first grade or kindergarten are not subject to this requirement. The reason for this is the straightforward proposition that parents should not be obligated to send their children to poor public schools for a year in order to gain eligibility for scholarship funding. As a

220. See, e.g., FlA. STAT. § 1002.395(3) (2012) (limiting scholarships to students who qualify for the free or reduced-price lunch program); Child Nutrition Programs; Income Eligibility Guidelines, 78 Fed. Reg. 17,628, 17,630 (Mar. 29, 2013), available at http://www.fns.usda.gov/cnd/governance/notices/iegs/IEG_Table-032913.pdf (last visited May 17,2013 ) (setting a family of four's reduced-price and free lunch thresholds in the contiguous United States to $\$ 43,568$ and $\$ 30,615$, respectively).

221. Additionally, some states have incorporated a poorly-conceived version of this restriction. For example, Georgia's law does not explicitly require that students have actually attended a public school in order to become eligible for scholarship funding. Instead, it merely requires that students have been enrolled in a public school. Predictably, some parents have simply enrolled their children in public schools for the purpose of establishing eligibility. See supra note 196 and accompanying text. 
consequence, however, any child entering kindergarten or first grade in these states is eligible for funding, rendering this restriction of limited practical value.

Because none of the approaches adopted by states is ideal, I propose a framework that incorporates the first two approaches in a novel and flexible way. States should reject the third eligibility restriction because, as noted, it is of limited practical value and, further, it is unnecessary under the combined approach I describe. The particular numbers and percentages I propose below are subject to debate. Reasonable people may offer different suggestions, and different states may have different needs, depending on socioeconomic and geographic characteristics and the condition of their public schools. However, the numbers I offer are useful both for illustrative purposes and to set a baseline for debate.

First, eligibility would be means-tested. However, rather than setting a hard cap at an arbitrarily low income level, states should adopt a graduated approach. Under such a system, those with lower incomes would qualify for larger scholarships than those with higher incomes. For example, households earning up to $200 \%$ could be eligible for unlimited tuition scholarships from scholarship organizations. Families earning between $200 \%$ and $400 \%$ of the federal poverty level would be eligible for a smaller scholarship amount, and those earning between $400 \%$ and $600 \%$ would be eligible only to receive a scholarship worth a small fraction of their tuition. Higher earners would be ineligible altogether. This graduated approach recognizes that even middle-income families often cannot afford private school tuition, yet it still gives preference to the truly needy and prohibits the truly wealthy from subsidizing their own children's tuition through this tax-advantaged program.

Second, scholarship organizations should be obligated to spend at least $70 \%$ of their scholarship funding on children otherwise zoned for failing public schools or to students who are performing poorly in otherwise acceptable public schools. ${ }^{222}$ This requirement ensures that scholarship organizations direct a substantial amount of their funding to students who clearly require it due to their educational needs while at the same time providing the organizations with the ability to assess students' educational needs beyond a one-size-fits-all assessment.

This dual approach, an imperfect version of which has been adopted by Alabama, will make certain that tuition tax credit programs do not simply

222. If after two years in the new school such a child shows no meaningful improvement, he or she should be deemed ineligible for further funding since the private school is having no more success educating the child than his or her public school was. 
become a means of subsidizing the private school tuition of the wealthy. Simultaneously, it provides scholarship organizations with the flexibility necessary to assist parents and schools of various means and in different situations. Finally, by requiring scholarship organizations and participating private schools to provide data to the public about how this public funding is being spent-which children and which schools are receiving it-we can track the effects and success of the program and thus assess its value.

\section{B. Educational Accountability}

Accountability in education, by which we typically mean standardized testing, is among the most controversial subjects in the field. ${ }^{223}$ It raises questions about the nature of learning and the project of teaching, and it is also implicated in debates about teachers' unions, tenure, pay, and performance. ${ }^{224}$ Consequently, different states have implemented the federal No Child Left Behind Act's testing requirements differently. ${ }^{225}$ Moreover, many educators oppose what they see as a fetishization of standardized testing, ${ }^{226}$ and private schools, which are not bound by the No Child Left Behind act, sometimes choose not to administer them. ${ }^{227}$ In designing a tax credit program, therefore, policymakers must consider carefully whether to require participating private schools to administer such tests and, if so, how.

223. Andrea Rodriguez, Comment, Revealing the Impurities of Ivory Soap: A Legal Analysis of the Validity of the Implementation of the No Child Left Behind Act, 10 SCHOLAR 75, 96 (2007); Motoko Rich, Holding States and Schools Accountable, N.Y. TIMES, Feb. 9, 2013, at A25.

224. See Johnson, supra note 105 (reporting resistance in Seattle and elsewhere to greater reliance on standardized testing); Banchero, supra note 105 (discussing greater resistance to standardized testing by those believing that testing stifles teaching).

225. See Regina R. Umpstead, The No Child Left Behind Act: Is It an Unfunded Mandate or a Promotion of Federal Educational Ideals?, 37 J.L. \& EDUC. 193, 216-17 (2008) (noting the act's aspiration to improve academic performance "by requiring states to devise and implement their own challenging academic standards and accountability systems").

226. See, e.g., Kevin G. Welner, Assessing Teachers Without Fetishizing Test-based Reforms, WASH. POST BLOG (Dec. 7, 2010, 5:00 AM), http://voices.washingtonpost.com/answer-sheet/guest-bloggers/assessing-teachers-withoutfet.html (proposing the use of holistic criteria to assess school effectiveness rather than relying on student scores and standardized tests).

227. Forman, supra note 21, at 551; Theresa Lelinski, The No Child Left Behind Act: Do We Really Want It to Leave All Religion Behind?, 10 Rutgers J. L. \& RELIGION 67, 68-69 (2008). 
Once again, states have taken different approaches. Some require no testing. ${ }^{228}$ Others require only students awarded scholarships to be tested. ${ }^{229}$ And still others require all participating private schools to administer standardized tests to all students. ${ }^{230}$

I propose that all students at private schools that receive public funds through tax credit scholarship programs should be required to take the same standardized tests that are required for students in the public schools, with the same exceptions that exist for public school students. Further, private schools that do not produce satisfactory testing results should be disqualified from receiving such scholarship funding.

If a primary purpose of adopting a tax credit scholarship program is to improve educational outcomes, then we must have some means of assessing whether they are doing so. To be sure, standardized tests have many problems and limitations, ${ }^{231}$ and we can reasonably debate whether they are effective tools for evaluating teachers' or students' performance. But if we require them of public schools and judge public schools by their resultsand if we tie scholarship eligibility to them, as I have proposed-then it is because we have decided that they are the best available resource for such assessments. Surely, then, we should also require them of private schools that enjoy privileged status thanks to these programs, and private schools that do not measure up should not be treated favorably. Of course, private schools that do not wish to administer standardized tests would not be

228. Six states lack a testing mandate: Arizona, Georgia, New Hampshire, Oklahoma, Pennsylvania, and Rhode Island.

229. Three states require testing for scholarship recipients: Florida, Louisiana, and Virginia. FLA. STAT. § 1002.395(8)(c)(2) (2012); LA. REV. STAT. § 47:6301(B)(2)(a)(ii) (2012); VA. CoDE $\S 58.1-439.28(\mathrm{D})$ (2013).

230. Three states require testing for all students at participating schools: Alabama, Indiana, and Iowa. Alabama Accountability Act of 2013, 2013 Ala. Laws Act 2013-64, § 9(c)(2)(a)(1) (2013); IND. CODE $\S 20-51-1-4.7$ (2012); IOWA CODE $\S 422.11 \mathrm{~S}(5)(\mathrm{b})$ (2013).

231. See, e.g., Jennifer Mueller, Facing the Unhappy Day: Three Aspects of the High Stakes Testing Movement, 11 KAN. J.L. \& PUB. POL'Y 201, 204 (2002) (“The concerns expressed by opponents of high stakes testing range from the philosophical disagreements of those who see the increase in testing as an anathema to traditional educational values to the psychometric concerns of researchers looking past the more widely publicized statistics and theories to the actual results of the programs."); Hagit Elul, Note, Making the Grade, Public Education Reform: The Use of Standardized Testing to Retain Students and Deny Diplomas, 30 Colum. HuM. RTS. L. REV. 495, 499-500 (1999) (noting common concerns about testing, such as students being personally accountable for institutional problems and bias against minorities); Leonie Haimson, Op-Ed., Tests Don't Assess What Really Matters, N.Y. TIMES, Aug. 21, 2012, http://www.nytimes.com/roomfordebate/2012/07/29/can-school-performance-be-measuredfairly/tests-dont-assess-what-really-matters (criticizing the overemphasis of standardized testing in evaluating teachers and schools despite the National Academy of Science's warning against high stakes accountability). 
required to; they would simply not be able to receive funding from scholarship organizations.

Incorporating such a testing requirement would have at least three positive consequences. First, we can use such tests to determine how public school education compares to that offered by participating private schools. Testing would thus help us decide whether this method of providing for school choice is a good use of taxpayer funds. Second, by making the aggregate test results publicly available-just as public schools' results are publicly available - parents, particularly those looking to escape from poor public schools, would have access to useful information when they select private schools for their children.

Third, by testing all students in participating private schools, many more parents will be incentivized to participate in public debates about the value of standardized testing. Currently, those people whose children attend private schools - often the most affluent and politically powerful and motivated among the population ${ }^{232}$ - have little at stake in this broad social debate. By applying the same rules to their children (assuming their private schools will accept such scholarship funding) as apply to children in public schools, these parents too will have skin in the game. Those who believe that testing is useful and beneficial will be pleased; those who disagree will be motivated to advocate for changes that will apply systemically rather than just to their own children.

\section{Total Expenditures, Tax Credit Value, and Contribution Limits}

States must also consider several fiscal issues: (1) how much money to divert from other public funding to these scholarships?; (2) what percentage of a contribution to a scholarship organization can be claimed as a tax credit?; and (3) what is the maximum amount that a taxpayer can receive as a tax credit? As demonstrated above, states have differed radically concerning these questions. Because they are so dependent on factors related to the state budget and priorities, it is impossible to provide any hard and fast answers to these questions. The best that can be said is that states must carefully consider what their other needs are and act prudently not to channel money to private schools at the expense of these other programs. Further, if states follow the framework I have proposed concerning

232. See WALBERG, supra note 7, at 64 tbl.4-2 (listing the percentages of private school students among freshmen at elite colleges and universities); Private Schooling, EDUC. WEEK, Aug. 4, 2004, http://www.edweek.org/ew/issues/private-schooling/ (summarizing statistics showing that the ability to attend private school is stratified). 
scholarship eligibility, because that framework creates a program that primarily directs these funds to the relatively needy rather than to the wealthy, it is unlikely that powerful interest groups will see much value in overfunding this program.

\section{Conclusion: The Best Practice That Matters Most}

Politics makes strange bedfellows, as the old saying goes, and this is perhaps never more accurate than with respect to the school choice movement. There are two distinct groups pushing for the school choice cause. ${ }^{233}$ On the one hand, some advocates for school choice view providing alternative educational options as a potential avenue out for students from relatively underprivileged backgrounds who are stuck in underperforming schools. ${ }^{234}$ To these reformers, the purpose of the school choice movement, and indeed of public education more broadly, is essentially redistributive. That is, they see education as a public good, and believe that the cost of education should be distributed across society progressively. This is because society as a whole enjoys the benefits of a well-educated population, and it pays the price when the educational system fails. ${ }^{235}$ Thus, when the traditional public school model fails those who cannot afford alternatives, these reformers maintain that school choice programsincluding charter schools, magnet schools, vouchers, and tax credit scholarship programs - facilitate access to better opportunities. ${ }^{236}$

233. Cf. Minow, supra note 20, at 829 (noting that despite possible constitutional concerns with directing public dollars to private religious schools, "advocates for poor children of color joined forces with free-market supporters and endorsers of public aid for parochial schools to seek publicly funded school choice programs that would include private religious schools").

234. See Zelman v. Simmons-Harris, 536 U.S. 639, 676-84 (2002) (Thomas, J. concurring) (arguing that school choice programs best advance the principles of Brown $v$. Board of Education by providing poor urban families in failing urban public school districts with "the best education for their children, who will certainly need it to function in our high-tech and advanced society"); Harry Brighouse, Educational Equality and Varieties of School Choice, in SCHOOL CHOICE POLICIES AND OUTCOMES, 41, 41-59 (Walter Feinberg \& Christopher Lubienski eds., 2008) (arguing that educational equality should be the driving principle of school choice programs).

235. See David F. Labaree, Public Goods, Private Goods: The American Struggle over Educational Goals, 34 AM. EDUC. RES. J. 39, 42 (1997) (describing the social efficiency approach's view of education "as a public good designed to prepare workers to fill structurally necessary market roles").

236. See, e.g., Garnett, supra note 16, at 202 (advocating for tax incentives to subsidize private school and enhance urban development); Isabel Chou, Note, "Opportunity" for All?: How Tax Credit Scholarships Will Fare in New Jersey, 64 RUTGERS L. REV. 295, 300 (2011) 
On the other hand, some school choice advocates believe that parents of all children should be able to choose how to educate their children and to direct their education dollars accordingly. ${ }^{237}$ This group views education primarily as a private good, the benefits of which are reaped by the child herself and her family. ${ }^{238}$ For this group, redistributive economics is of profoundly lesser importance in the educational context than is accommodating the ability of parents to educate their children as they see fit, provided they have the means to do so.

These two groups have made common cause to push a variety of changes to the ecology of public education, and in particular with respect to the modern tax credit scholarship programs. The promise of such programs is that they appear to be win-win, because they can provide scholarships for children in need and also provide both tax advantages and scholarships to the less needy. The trouble is that these two interests are at war with one another. Even as such programs may be sold to the public as efforts to help the underprivileged, they may be designed in ways that serve primarily those who would send their children to private schools even without financial aid. Indeed, such programs can sit anywhere on a spectrum from broadly redistributive to essentially a direct tax credit for those who send their own children to private schools. Thus, the true effect of a tax credit scholarship program is primarily a function of how it is structured.

The choice between the two competing visions for public education is ultimately an ideological, philosophical, and political one. Thus, the prescriptions I have offered should be recognized as picking a side in this debate, and those who disagree with the underlying substantive claim will consequently - and reasonably - disagree with the prescriptions. The central trouble, though, lies in the dichotomy between how these programs are sold versus how they are designed to function. This problem should preoccupy

(expressing school-choice supporters' view that "in low-income urban communities, school choice programs are seen as the only lifeline for parents of children in failing public schools").

237. See, e.g., Reich, supra note 20, at 21 (arguing that "the legitimacy of school choice is founded in liberty" because "[p]ermitting parents to select a school for their children is crucial to respecting the liberty interests of parents. To be more specific, liberal societies must protect some version of school choice because the normative significance of pluralism requires the state to protect the liberty interests of parents to rear their children in some rough accordance with their deepest ethical or religious convictions."); Our Position (School Choice), FOCUS ON THE FAMILY, http://www.focusonthefamily.com/socialissues/social-issues/school-choice/ourposition.aspx (last visited Nov. 20, 2013) (highlighting that public school curriculum can inhibit parents from raising their children with certain religious beliefs).

238. See Labaree, supra note 235 , at 42 ("[T]he perspective of the individual educational consumer [sees education] as a private good designed to prepare individuals for successful social competition for the more desirable market roles.”). 
anyone concerned with good governance, regardless of ideological commitments.

If what a person really wants is a direct subsidy that assists all parents in sending children to the private schools of their choice, then the least we can expect is truthfulness in the marketing of such plans. For example, rather than promote a convoluted indirect tax credit scholarship program, such a person should advocate a direct credit or voucher program. Convince the public that this is a worthwhile way to spend money that would otherwise be spent on public schools and other public programs. In the end, there is really only one best practice that matters: honesty. 